\title{
Arqueologia dos Cerritos na Laguna dos Patos, Sul do Brasil: uma síntese da ocupação regional
}

\author{
Rafael Guedes Milheira*, Anderson Marques Garcia ${ }^{* *}$, Bruno Leonardo Ricardo Ribeiro ${ }^{\star * *}$, \\ Priscilla Ferreira Ulguim ${ }^{\star * * *}$, Cleiton Silva da Silveira ${ }^{\star * * * *}$ e Marcelo da Silva Sanhudo M $^{\star * * * * *}$
}

Palavras-chave: Arqueologia dos Cerritos; Ambientes Construídos; Ocupação regional.

Keywords: Earthen Mounds; Built Environment; Regional Settlement.
Resumo: Desde o século XIX, são pesquisados sítios arqueológicos compostos por montículos predominantemente de terra denominados cerritos ou aterros, associados a estruturas como microrrelevos, negativos topográficos, caminhos e praças que configuram complexos arqueológicos comumente encontrados em ambientes alagadiços no bioma Pampa, entre o sul do Brasil, Uruguai e Argentina. No Brasil, na porção meridional da Laguna dos Patos, a arqueologia dos cerritos vem sendo retomada depois de 40 anos de "esquecimento". Já foram realizados mapeamentos de três complexos de sítios com cerritos e desenvolvidas intervenções sistemáticas para compreensão dos contextos arqueológicos; estudos de tecnologias, dieta alimentar e processos de formação, bem como estabelecimento de cronologias. Esses dados foram sintetizados neste artigo para discutir a relação sistêmica entre as diferentes áreas de ocupação no ambiente lagunar do estuário da Laguna dos Patos.

Abstract: The cerritos, or atteros have been the focus of archaeological research since the nineteenth century. These are earthen mounds which are related to both microrelief fill features, cut features, pathways and plazas which, together, comprise the archaeology of the swamp environments in the Pampa biome of southern Brazil, Uruguay and Argentina. Recently, archaeological research returned to sites in the south of Brazil, at Laguna dos Patos after 40 years of "forgetfulness". Three cerritos complexes were surveyed, and analyses conducted in order to better understand the archaeological contexts. These included technological studies, analysis of diet, formation processes as well as chronology. This paper presents a synthesis of the data in order to discuss the relationship between different occupations of the lagoon environment of the Laguna dos Patos estuary.

Recebido em 17 de dezembro de 2015. Aprovado em 24 de junho de 2016.

\section{Introdução: relembrando e atualizando o tema da arqueologia dos cerritos do bioma pampa}

Na bacia hidrográfica da Laguna dos Patos e Lagoa Mirim, são encontrados sítios arqueológicos conhecidos como "cerritos de índios" ou "aterros dos campos do sul". Os cerritos, como denominaremos tais estruturas em nosso texto - em conformidade com a nomenclatura platina -, são estruturas arqueológicas monticulares constituídas predominantemente de terra e materiais como arqueofauna, instrumentos líticos e cerâmicos, além de apesentarem estruturas de fogueiras e enterramentos humanos. Encontramse no Sul da América do Sul, distribuídos nas porções Leste e Norte do Uruguai (CABRERA, 2013; BRACCO; CABRERA; LOPEZ MAZZ, 2000; LOPEZ MAZZ, 2001; LOPEZ MAZZ; GIANOTTI,

* Professor do Departamento de Antropologia e Arqueologia e do Programa de Pós-Graduação em Antropologia da Universidade Federal de Pelotas (UFPel). Professor do Programa de Pós-Graduação em Patrimônio Cultural da Universidade Federal de Santa Maria (UFSM). Coordenador do Laboratório de Ensino e Pesquisa em Antropologia e Arqueologia (LEPAARQ/UFPel). E-mail: milheirarafael@gmail.com

*Doutorando em Arqueologia pelo Museu Nacional da Universidade Federal do Rio de Janeiro (UFRJ). Mestre em Patrimônio Cultural pela Universidade Federal de Santa Maria (UFSM). Colaborador do Laboratório de Ensino e Pesquisa em Antropologia e Arqueologia da Universidade Federal de Pelotas (LEPAARQ/UFPel). E-mail: andersonmarquesgarcia@gmail.com

${ }^{* * *}$ Graduando do curso de Bacharelado em Antropologia, com linha de formação em Arqueologia da Universidade Federal de Pelotas (UFPel). Bolsista Pibic-CNPQ do Laboratório de Ensino e Pesquisa em Antropologia e Arqueologia (LEPAARQ/UFPel). E-mail: brunoleo.ribeiro@gmail.com

${ }_{* * * *}^{*}$ Doutoranda em Bioarqueologia e Antropologia Biológica - Teesside University, UK. E-mail: priscillaulguim@hotmail.com

${ }^{* * * *}$ Arqueólogo, pesquisador do Laboratório de Ensino e Pesquisa em Antropologia e Arqueologia da Universidade Federal de Pelotas (LEPAARQ/ UFPel). E-mail: arqueo.cleiton@gmail.com

${ }^{* * * * * *}$ Mestrando em Arqueologia pelo Programa de Pós-Graduação em Antropologia da Universidade Federal de Pelotas (UFPel). Colaborador do Laboratório de Ensino e Pesquisa em Antropologia e Arqueologia (LEPAARQ/UFPel). E-mail: m.sanhudo@yahoo.com.br 
1998; LOPEZ MAZZ; BRACCO, 2010; IRIARTE, 2006; BRACCO; DEL PUERTO; INDA, 2008; VILLAGRAN; GIANOTTI, 2013); Sul do Brasil, na metade sul do Rio Grande do Sul (SCHMITZ, 1976; COPÉ, 1992; RÜTHSCHILLING, 1989; QUINTANA, 2010; LOUREIRO, 2008; ULGUIM, 2010; BELLETTI, 2010; PEÇANHA, 2014; MILHEIRA; PEÇANHA; MÜHLEN, 2014; MILHEIRA et al 2017); porção Nordeste da Argentina, no Delta do rio Paraná (LOPONTE; ACOSTA, 2008; LOPONTE, 2010; BONOMO; POLITIS; GIANOTTI, 2011; BONOMO, 2012).

No que se refere à continuidade histórica, os cerritos localizados entre o Brasil e Uruguai são interpretados como construções resultantes da ocupação dos grupos Charrua e Minuano (SERRANO, 1946; BASILE-BECKER, 1992, 2002); já na Argentina, a associação é feita com os Chaná-timbú (BONOMO; POLITIS; GIANOTTI, 2011; BONOMO, 2012), que comporta grupos indígenas bastante conhecidos historicamente pelos abundantes relatos de viajantes e cronistas a partir do século XVI. No entanto, essa correlação etnográfica não é consensual por dois motivos: 1) segundo Lopez Mazz e Bracco (2010), seria mais coerente afirmar que a região das bacias da Laguna dos Patos e Lagoa Mirim, principal área de dispersão dos cerritos, teria sido ocupada apenas pelos grupos Minuano, inimigos tradicionais dos Charrua; 2) é sempre perigoso, do ponto de vista historiográfico, extrapolar categorias étnicas históricas coloniais a um passado pré-colonial de longa duração e realizar analogias com uma sociedade com aproximadamente 5 mil anos de história. ${ }^{1}$

Quanto aos estudos relativos à função dessas estruturas, podemos afirmar que os cerritos são pensados como áreas de sepultamentos, demarcadores territoriais, áreas de descarte de refugo, plataformas arquitetônicas erguidas para a habitação em áreas alagadiças ou mesmo monumentos que remontam à memória histórica e à identidade social contemporânea dos índios pampeanos. Tais estruturas arqueológicas alcançam um horizonte cronológico de 4.500 A.P. em sítios do interior do território uruguaio, onde atingem dimensões de $100 \mathrm{~m}$ de diâmetro e até $7 \mathrm{~m}$ de altura (BRACCO; DEL PUERTO; INDA, 2008). Apresentam indícios de monumentalidade pelas suas dimensões e pelos seus processos construtivos, além de serem tratados como indicadores de complexidade social. São encontrados isolados na paisagem ou em conjuntos que chegam até 52 cerritos; e, nesses casos, são tratados como sítios compostos. Sua distribuição geográfica - embora ocorra em ambientes de distintas altimetrias, ao longo dos terrenos planos e de terrenos ondulados das terras baixas platinas - está geralmente ligada a unidades edáficas, como banhados e charcos (BRACCO; CABRERA; LOPEZ MAZZ, 2000; GIANOTTI, 2000; PINTOS BLANCO, 2000; BOADO; GIANOTTI; BORRAZÁS, 2006; LOPEZ MAZZ; BRACCO, 2010; BONOMO; POLITIS; GIANOTTI, 2011).

Na porção meridional da Laguna dos Patos, os cerritos ocorrem na paisagem de forma menos imponente, alcançando dimensões que chegam até $70 \mathrm{~m}$ de diâmetro e $2 \mathrm{~m}$ de altura, com uma profundidade temporal entre 2.500 A.P até 200 A.P. (SCHMITZ, 1976). No trabalho de maior fôlego até então publicado sobre o tema no Brasil, Schmitz (1976) interpretou os cerritos na Laguna dos Patos, mais especificamente na região do município de Rio Grande, como montículos utilizados para acampamentos sazonais de pesca lacustre ocupados em períodos de verão. Neste caso, os cerritos seriam vestígios arqueológicos indicadores de um comportamento ecológico-adaptativo destas populações em ambientes alagadiços, típicos dos banhados do bioma pampa. Passados quase 40 anos da publicação do modelo clássico de Schmitz (1976), trabalhos pontuais foram realizados no Brasil, de forma que o tema da arqueologia dos cerritos tornou-se parcialmente "esquecido". Esse cenário de esquecimento contrasta significativamente com o ambiente arqueológico-acadêmico uruguaio, onde os cerritos são tema central de pesquisa desde, pelo menos, os anos 1990.

\section{Pesquisas em complexos com cerritos no município de Pelotas e região}

\section{Área de estudo}

Na margem sudoeste da Laguna dos Patos, especificamente entre os municípios de Pelotas e 
Capão do Leão/RS, os estudos em cerritos vêm sendo desenvolvidos desde o ano de 2002, por meio de diversos projetos de pesquisa realizados pelo Laboratório de Ensino e Pesquisa em Antropologia e Arqueologia da Universidade Federal de Pelotas (LEPAARQ/UFPel). A partir desses trabalhos, já foram identificados 30 sítios ocupados pelos grupos construtores de cerritos em três localidades distintas. Ao longo do tempo, vários trabalhos e produtos foram gerados por pesquisadores distintos, que se utilizaram de técnicas e métodos diferenciados, tanto de análises como de sistematização de informações e interpretações; por isso, é praticamente impossível sintetizar um artigo contendo o mesmo padrão de dados e linhas interpretativas, embora tenhamos feito um esforço nesse sentido para a composição deste texto.

É importante, também, destacarmos que serão apresentados diferenciadamente os cerritos (estruturas construídas) e as ocupações em albardões naturais, contextos sem indícios de deposição intencional de sedimento. Embora seja evidente que os conjuntos artefatuais dos sítios construídos e não construídos remetam a um mesmo grupo cultural, os tipos de sítios correspondem a distintas formas de ocupação, manejo de sedimentos e apropriações e transformações topográficas, gerando marcas diferenciadas na paisagem. Trata-se, ainda, de problematizar a "naturalização" do termo cerrito como um tipo de sítio arqueológico de conformação homogênea, uma vez que as estruturas compostas ou simplesmente ocupadas pelos grupos que chamaremos de "construtores de cerritos" ou apenas "cerriteiros" são variadas em forma e conteúdo, sendo comum na literatura a descrição de negativos topográficos, microrrelevos, diques, lagoas construídas ou manejadas e praças que ocorrem em associação aos montículos (BRACCO; CABRERA; LOPEZ MAZZ, 2000; GIANOTTI, 2000; BRACCO; DEL PUERTO; INDA, 2008; LOPEZ MAZZ; BRACCO, 2010; BONOMO; POLITIS; GIANOTTI, 2011).

Além disso, utilizaremos o termo sítio arqueológico para referenciar cada estrutura arqueológica, partindo do pressuposto que sítio arqueológico é a unidade arqueológica contextual mínima de análise. Conjuntos de estruturas geograficamente articuladas em uma relação sistêmica compõem um complexo de sítios arqueológicos que pode envolver ambos os tipos de estruturas, construídas ou não construídas. A partir desses trabalhos, foram mapeados: um sítio isolado na Ilha da Feitoria, um complexo de sítios no banhado do Pontal da Barra (18 sítios) e um complexo no banhado da lagoa do Fragata (11 sítios).

A área de pesquisa do projeto localiza-se na Planície Costeira, formada a partir de 400.000 A.P., por um processo de formação ligado a eventos de deposição sedimentar descontínuos e paralelos à costa, conhecido como Sistema Laguna-Barreira (TOMAZELLI; VILLWOCK, 2000; BRASIL, 1986). Esse processo é marcado por, pelo menos, quatro barreiras de sedimentos transportados durante as últimas transgressões e regressões marinhas ocorridas entre o Terciário e o Quaternário que isolaram e formaram corpos lagunares, como é o caso do sistema lagunar Patos-Mirim, originário do Holoceno e com idade de 5.500 anos A.P. aproximadamente. A estrutura geológica atual da Planície Costeira é composta por depósitos de natureza marinha e continental, modelados pelas intempéries e sedimentações aluviais e fluviais, resultando em uma topografia complexa e diversificada, que envolve planícies de inundação, terraços e depósitos de calha de rede fluvial, terrenos planos, albardões, dunas e paleodunas (VILLWOCK et al., 1986; TOMAZELLI; VILLWOCK, 2000; BRASIL, 1986).

Como resultado desses processos transgressivos-regressivos, formaram-se diversas lagoas na Planície Costeira, abastecidas pela drenagem fluvial desde a serra, a Oeste, pelo oceano Atlântico, a Leste e pela precipitação. A bacia hidrográfica da Laguna dos Patos é o mais importante e volumoso entre os corpos lagunares da Planície Costeira do Rio Grande do Sul, banhando uma região de aproximadamente $10.227 \mathrm{~km}^{2}$. Liga-se à Lagoa Mirim, fronteira com o Uruguai, através do canal São Gonçalo, o qual, por sua vez, estende-se por uma planície sedimentar holocênica. Com um traçado bastante sinuoso, o canal São Gonçalo possui uma extensão de aproximadamente $75 \mathrm{~km}$ com larguras variáveis de até $200 \mathrm{~m}$ e profundidades de até $6 \mathrm{~m}$.

A ampla variabilidade geomorfológica regional é responsável por um complexo mosaico 
vegetal, variando de composições herbáceas, arbustivas e arbóreas, um sistema classificado como "Complexo de Restinga" (RIZZINI, 1997). As Matas de Restinga localizam-se na orla das lagoas e Laguna dos Patos, tendo sido mais abundantes no passado. São florestas de pequeno porte e espécies arbóreas adaptadas às fortes ações dos ventos litorâneos, conhecidas como Matas paludosas e Matas psamófilas, caracterizadas por ocuparem antigas linhas de paleopraias fixadas pela associação com a vegetação, de onde resulta sua formação de capões alongados, mais ou menos paralelos com a costa litorânea (MAUHS; MARCHIORETTO, 2006; VENZKE; FERRER; COSTA, 2012).
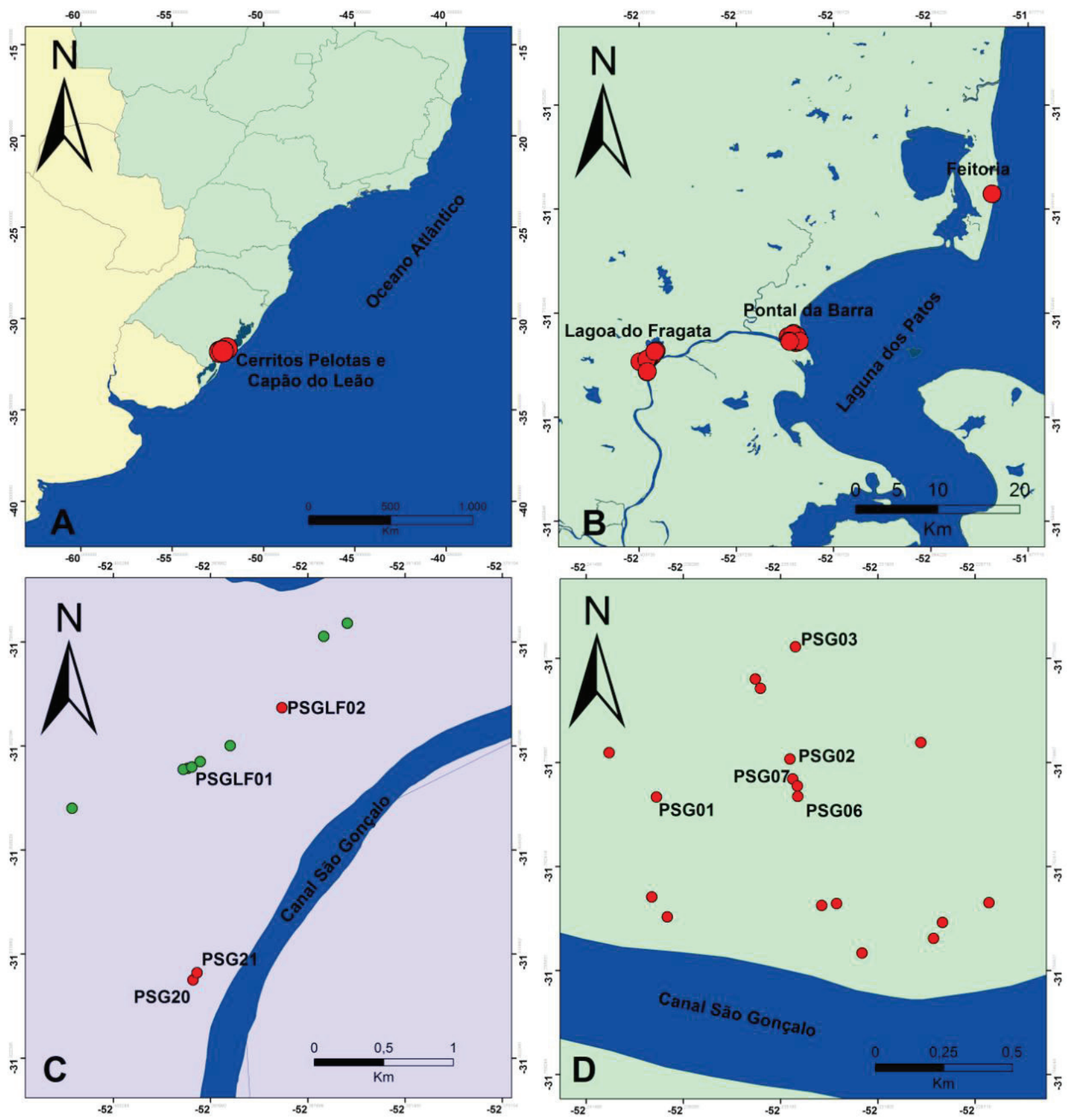

Mapa 1 - A) mapa arqueológico localizando os cerritos de Pelotas e Capão do Leão, na porção sudoeste da Laguna dos Patos, no estado do Rio Grande do Sul; B) mapa com a localização dos cerritos no banhado da Lagoa do Fragata, no banhado do Pontal da Barra e na ilha da Feitoria; C) mapa indicando os cerritos construídos (em vermelho) e não construídos (em verde) da Lagoa do Fragata; D) mapa indicando os cerritos datados no Pontal da Barra Fonte: Elaborado por Rafael Milheira. 
Tabela 1 - Tabela dos cerritos localizados nos municípios de Pelotas e Capão do Leão, contendo localidade, nome do sítio, sigla e coordenadas geográficas

\begin{tabular}{|c|c|c|c|c|c|c|}
\hline Cidade & Localidade & Nome do Sítio & Sigla & Zona & $\mathbf{X}$ & $\mathbf{Y}$ \\
\hline Pelotas & Ilha da Feitoria & Cerrito da Sotéia & PT-02 & $22 J$ & 403510 & 6500979 \\
\hline Capão do Leão & Lagoa do Fragata & Lagoa do Fragata 01 & PSGLF-01 & $22 J$ & 367785 & 6480485 \\
\hline Capão do Leão & Lagoa do Fragata & Lagoa do Fragata 02 & PSGLF-02 & $22 J$ & 368475 & 6480924 \\
\hline Capão do Leão & Lagoa do Fragata & Lagoa do Fragata 03 & PSGLF -03 & $22 J$ & 368161 & 6480648 \\
\hline Capão do Leão & Lagoa do Fragata & Lagoa do Fragata 04 & PSGLF -04 & $22 J$ & 367903 & 6480481 \\
\hline Capão do Leão & Lagoa do Fragata & Lagoa do Fragata 05 & PSGLF -05 & $22 J$ & 367876 & 6480474 \\
\hline Capão do Leão & Lagoa do Fragata & Lagoa do Fragata 06 & PSGLF -06 & $22 J$ & 367198 & 6480187 \\
\hline Capão do Leão & Lagoa do Fragata & Lagoa do Fragata 07 & PSGLF -07 & $22 J$ & 367980 & 6480531 \\
\hline Pelotas & Lagoa do Fragata & Pavão 01 & PSG-20 & $22 J$ & 367955 & 6478964 \\
\hline Pelotas & Lagoa do Fragata & Pavão 02 & PSG-21 & $22 J$ & 367980 & 6479016 \\
\hline Pelotas & Lagoa do Fragata & Moreira 01 & PSGLF -08 & $22 J$ & 368868 & 6481536 \\
\hline Pelotas & Lagoa do Fragata & Moreira 02 & PSGLF -9 & $22 J$ & 368725 & 6481439 \\
\hline Pelotas & Pontal da Barra & Valverde 1 & PSG-01 & $22 J$ & 382670 & 6483267 \\
\hline Pelotas & Pontal da Barra & Valverde 2 & PSG-02 & $22 J$ & 383084 & 6483410 \\
\hline Pelotas & Pontal da Barra & Valverde 3 & PSG-03 & $22 J$ & 383096 & 6483819 \\
\hline Pelotas & Pontal da Barra & Valverde 4 & PSG-04 & $22 J$ & 382521 & 6483427 \\
\hline Pelotas & Pontal da Barra & Valverde 5 & PSG-05 & $22 J$ & 383108 & 6483312 \\
\hline Pelotas & Pontal da Barra & Valverde 6 & PSG-06 & $22 J$ & 383110 & 6483274 \\
\hline Pelotas & Pontal da Barra & Valverde 7 & PSG-07 & $22 J$ & 383093 & 6483337 \\
\hline Pelotas & Pontal da Barra & Valverde 8 & PSG-08 & $22 J$ & 383538 & 6482762 \\
\hline Pelotas & Pontal da Barra & Valverde 9 & PSG-09 & $22 \mathrm{~J}$ & 383565 & 6482820 \\
\hline Pelotas & Pontal da Barra & Valverde 10 & PSG-10 & $22 J$ & 383316 & 6482706 \\
\hline Pelotas & Pontal da Barra & Valverde 11 & PSG-11 & $22 J$ & 383189 & 6482878 \\
\hline Pelotas & Pontal da Barra & Valverde 12 & PSG-12 & $22 J$ & 383235 & 6482885 \\
\hline Pelotas & Pontal da Barra & Valverde 13 & PSG-13 & $22 J$ & 383490 & 6483475 \\
\hline Pelotas & Pontal da Barra & Valverde 14 & PSG-14 & $22 J$ & 382989 & 6483666 \\
\hline Pelotas & Pontal da Barra & Valverde 15 & PSG-15 & $22 J$ & 382973 & 6483700 \\
\hline Pelotas & Pontal da Barra & Valverde 16 & PSG-16 & $22 J$ & 383709 & 6482894 \\
\hline Pelotas & Pontal da Barra & Valverde 17 & PSG-18 & $22 J$ & 382660 & 6482903 \\
\hline Pelotas & Pontal da Barra & Valverde 18 & PSG-19 & $22 J$ & 382709 & 6482831 \\
\hline
\end{tabular}

Fonte: Banco de dados do LEPAARQ/UFPel.

\section{Cerrito da Ilha da Feitoria}

\section{Breve descrição da área de implantação do sítio}

O sítio arqueológico PT-02-Cerrito da Sotéia localiza-se na ilha da Feitoria, município de Pelotas, no Rio Grande do Sul. A ilha da Feitoria é um "esporão arenoso" típico da porção meridional da Laguna dos Patos. Trata-se de uma área composta por sedimentos síltico-argilosos de planície de inundação. São depósitos não consolidados, compostos por areias finas, médias e quartzosas de tonalidade esbranquiçada e caráter fluviolacustre, oriundos do assoreamento de lagoas costeiras e sedimentação aluvial. No caso, um dos componentes de maior sedimentação é o arroio Correntes, ao Norte da ilha, que a separa do continente (BRASIL, 1986). A sedimentação aluvial, além de formar o esporão arenoso conhecido como ilha da Feitoria, criou uma barreira sedimentar e um depósito de águas conhecido como Lagoa Pequena à Oeste, lugar que se tornou um grande criadouro de espécies aquáticas. 
O sítio PT-02 encontra-se isolado, não tendo sido encontrado nenhum outro sítio desse tipo no contexto da ilha da Feitoria. Situa-se a $200 \mathrm{~m}$ de sua margem Leste, em uma área de aproximadamente $170 \mathrm{~m}^{2}$ de área plana e terreno coberto por vegetação do tipo gramínea herbácea, com seus arredores (Leste e Oeste) cobertos por Vegetação Pioneira formando matas nativas, havendo matas em reflorestamento e plantio de eucalipto. Além disso, ocorrem áreas alagadiças (banhados) e matas galerias, estas são um registro das transgressões e regressões das águas da Laguna sobre o terreno da Ilha, cujas alturas oscilam em torno de $3 \mathrm{~m}$ em relação ao nível do mar (BRASIL, 1986). O terreno onde se localiza o montículo é utilizado como espaço de pecuária.

\section{Intervenções realizadas e descrição do sítio}

Foram realizadas três campanhas de escavações arqueológicas neste cerrito entre os anos de 2005 e 2008, com o objetivo de delimitar o sítio e ampliar as áreas escavadas para identificação e caracterização dos contextos arqueológicos. A topografia foi realizada em uma área de $80 \mathrm{~m}^{2} \mathrm{e}$ foram escavados, em níveis artificiais de $10 \mathrm{~cm}$, um total de $27,5 \mathrm{~m}^{2}$ em quadrículas de $1 \mathrm{~m}^{2}$ e trincheiras, desde o topo até a periferia do cerrito, e 32 sondagens de $0,5 \mathrm{~m}^{2}$ que cobriram uma área total de $1 \mathrm{~km}^{2}$. Dessa forma, pôde-se determinar que o cerrito tem planta com formato elipsoidal de $20 \mathrm{~m}$ no eixo NorteSul e $15 \mathrm{~m}$ no eixo Leste-Oeste e pacote arqueológico de $80 \mathrm{~cm}$ na área do topo e $50 \mathrm{~cm}$ nas extremidades da estrutura (LOUREIRO, 2008; BELLETTI, 2010).

O cerrito foi datado com a técnica radiocarbônica de Espectrometria de Massas com Aceleradores (MAS), através de amostras de otólito de peixe. Foram realizadas duas datações, cujas datas convencionais são de $1.400 \pm 40$ A.P. (1.053 a 852 A.P. calibradas com $2 \sigma$ ) para a base do Cerrito e de $1.360 \pm 40$ A.P. (997 a 788 A.P. calibradas com $2 \sigma$ ) (LOUREIRO, 2008; BELLETTI, 2010; GARCIA, 2010; GARCIA; MILHEIRA, 2011, 2013). Considerando o intervalo das datas em 2 sigma, é evidentemente impossível determinar temporalmente o início e o fim da construção do montículo, já que há um intervalo máximo de 265 entre a data mínima para base e máxima para o topo.

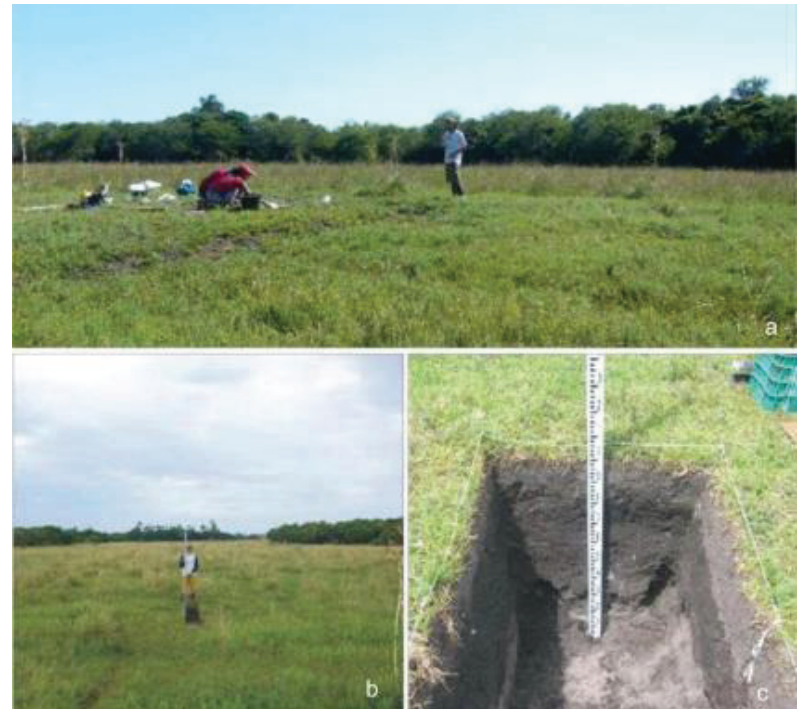

Figura 1 - Sítio PT-02 Cerrito da Sotéia, na Ilha da Feitoria. (a) Vista geral do cerrito no sentido LesteOeste, em que se nota a elevação do montículo em campo aberto; (b) vista geral do cerrito no sentido Norte-Sul durante realização de medições topográficas e escavação de trincheira; (c) escavação de sondagem, em que se pode notar a camada basal estéril com coloração clara, típica do solo natural da região e o pacote arqueológico com grande concentração de materiais, diferenciado entre camada com coloração cinza-escura/preta (mais úmida) e camada superior cinza claro (menos úmida) Fotos: Acervo do LEPAARQ/UFPel.

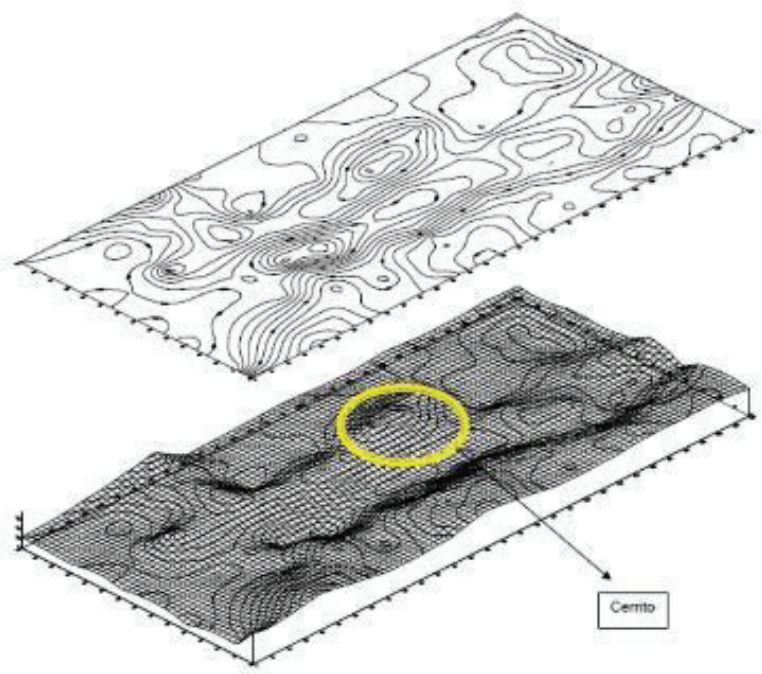

Figura 2 - Mapa topográfico do sítio PT-02: Cerrito da Sotéia e sua área adjacente Fonte: Retirado de Loureiro (2008).

\section{Tecnologia cerâmica}

Segundo Belletti (2010), foi coletado no cerrito PT-02 um total de 1.743 fragmentos de cerâmica, entre os quais foram analisadas 430 
peças, coleção essa com alto grau de fragmentação, em que $79 \%(\mathrm{n}=1.313)$ das peças analisadas têm dimensões menores do que $4,5 \mathrm{~cm}$. A análise feita pela autora apontou um predomínio de fragmentos de parede $(77,9 \% ; \mathrm{n}=335)$, seguido de bordas $(21,4 \%$; $\mathrm{n}=92)$ e bases $(0,7 \% ; n=3)$. A técnica de confecção das vasilhas é basicamente roletada com uso de antiplástico mineral, ocorrendo grãos de quartzo, feldspato e anfibolito, típicos minerais recorrentes em depósitos naturais de argila. A granulometria dos antiplásticos é predominantemente fina e média, com alta concentração da pasta da argila, oscilando em torno de $45,8 \%$ das peças analisadas $(\mathrm{n}=197)$. Quanto à queima, predominam valores de queima incompleta em $60 \%$ das peças analisadas $(n=258)$, tendendo a processos de queima redutora com núcleos e superfícies escurecidas, o que sugere processos de queima em fornos abertos de temperaturas abaixo de $550^{\circ}$. O Tratamento de superfície mais comumente encontrado é o alisado $(87,7 \% ; \mathrm{n}=377)$, o que contrasta com os tratamentos plásticos observados em apenas um fragmento e ocorrência de engobo predominantemente branco, que aparece em 7,2\% das amostras $(n=31)$. Quanto às formas das vasilhas, elas ocorrem predominantemente abertas $(51,1 \%$; $\mathrm{n}=21$ ) e com porcentagens menores de vasilhas paralelas $(27,2 \% ; n=11)$ e fechadas $(12 \% ; n=05)$, tendendo às bordas ocorrerem em forma direta ${ }^{2}$. Devido ao baixo índice de remontagem de vasilhas e à alta fragmentação, poucas foram as possibilidades de projeção de vasilhas a partir das bordas. Nas bordas em que se pôde medir o diâmetro, foi possível verificar uma variação de 5 a $54 \mathrm{~cm}$ de abertura da boca, com predominância de vasilhames com diâmetros no intervalo entre 17 a $28 \mathrm{~cm}(56 \%$; $\mathrm{n}=23)$. Destes, $19 \%$ das peças têm medidas entre 17 e $20 \mathrm{~cm}$ $(\mathrm{n}=8), 19 \%$ entre 21 e $24 \mathrm{~cm}(\mathrm{n}=8)$ e $17 \%$ entre 25 e 28 $\mathrm{cm}(\mathrm{n}=7)$. Para os demais vasilhames cujos diâmetros puderam ser inferidos, identificamos um total de oito potes com diâmetro de abertura de boca entre 5 e 16 $\mathrm{cm}(19 \%)$ e outros 13 vasilhames (32\%) com abertura de boca variando entre 29 e $54 \mathrm{~cm}$.

\section{Tecnologia Lítica}

A coleção de materiais líticos do cerrito PT02 é composta por 501 peças de distintas matériasprimas, entre as quais a mais representativa é o quartzo com 364 unidades, seguida por basalto com 49; andesito com 46; granito com 37; e riolito com cinco. Os primeiros estudos sobre a indústria lítica desse sítio podem ser vistos em maior detalhe em Garcia (2010) e em Garcia e Milheira $(2011,2013)$.

A indústria lítica sobre quartzo identificada no cerrito foi embasada principalmente na técnica de lascamento bipolar (técnica de bigorna), através da qual foram confeccionadas 196 peças entre lascas, núcleos e resíduos de lascamento. Além disso, 70 lascas foram obtidas através da técnica unipolar (percussão direta), 87 peças podem ser referentes a ambas as técnicas (estilhas) e 11 peças são naturais, sem estigmas de lascamento que nos permitam definir a técnica utilizada (percutores, artefatos brutos, fragmentos naturais e lascas térmicas).

A partir do quartzo, foi confeccionada a maior parte dos instrumentos, sobretudo aqueles com marcas de utilização ligadas a atividades de corte, raspagem e perfuração, sendo estes últimos os de maior representatividade numérica. Os instrumentos de perfuração foram lascas bipolares laminares que recebiam adequação morfológica em suas porções distais (e proximais em alguns casos) através de microrretiradas por pressão que tornavam os instrumentos bifaciais, morfologicamente triangulares e pontiagudos (Figura 3 ).
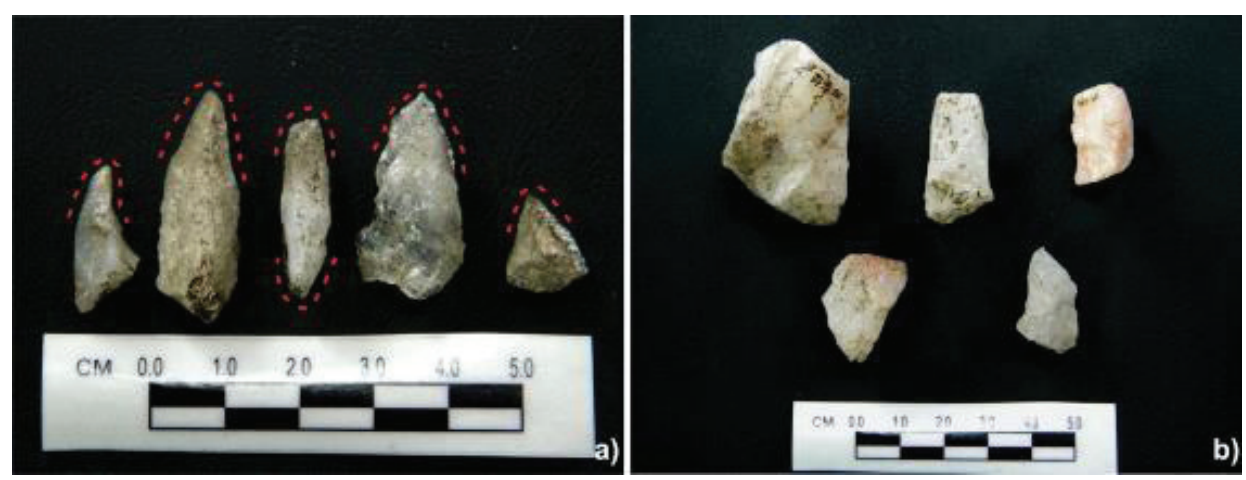

Figura 3 - a) instrumentos de perfuração com unidades transformativas indicadas pelo tracejado vermelho; b) núcleos bipolares relacionados à produção dos instrumentos de perfuração Fotos: Anderson Marques Garcia. 


\section{Vestígios arqueofaunísticos}

A arqueofauna constitui o vestígio mais abundante no contexto do cerrito PT-02. A análise realizada por Ulguim (2010) na quadrícula 49.30 (a qual foi datada) apontou um NISP de 70.636, atribuídos a 25 taxa e sete classes. Peixes, crustáceos e bivalves foram os vestígios arqueofaunísticos identificados de maior significância neste sítio. Com relação à classe Mammalia, o Cervídeo (Mazama sp.) e o Tatu-Galinha (Novemcinctus novemcinctus) foram os mais representativos com um MNI de 2 e 3 respectivamente. Entretanto, esses não contribuíram significativamente na contagem do NISP total. No que tange à ordem Rodentia, essa apresentou um MNI de um para o Ratão do Banhado (Mycastor coypus), e um MNI de cinco para a Preá (Cavea aperea).

Com relação à classe Osteichthyes, essa apresentou seis espécies das quais o Bagre (Netuma barba) representa o maior NISP, seguido da Corvina (Micropogonias furnieri) e da Miraguaia (Pogonias cromis), com quantidades menores de Bagre (Genidens genidens), Traíra (Hoplias malabaricus), e Tainha (Mugil sp.). No entanto, o Micropogonias furnieri é a espécie mais abundante em termos de MNI, MNIP e biomassa, seguido pelo Netuma barba e Pogonias cromis. A identificação dessa taxa é bastante similar à descrita por Schmitz (1976) em seu estudo sobre cerritos localizados também na Laguna dos Patos.

Com relação à classe Malacostraca, o Siri (Callinectes sp.) apresentou o segundo maior NISP, e um MNI de 164 para todos os níveis. Dos gastrópodes, o Aruá do Mato (Megalobulimus abbreviatus) apontou um MNI de 17 e NISP de 276. Dos bivalves, o mais abundante foi a Erodona mactroides, NISP de 7.121 e MNI de 1.226. Embora esse tipo de concha seja abundante em termos quantitativos na amostra, a identificação de valvas fechadas de pequenas dimensões sugere que esse bivalve não tenha sido utilizado como recurso alimentar. Por outro lado, o bivalve Diplodon sp., o qual aparece em pequenas quantidades, NISP $360 \mathrm{e}$ MNI 14, foi provavelmente coletado nas águas doces do arroio Corrientes para consumo.

A classe Osteichthyes apresentou os maiores valores de biomassa, 93\%, seguido pela classe Mammalia com 4\%, da Reptilia com 2\% e Malacostraca com 1\%. As espécies com maior biomassa são: a Corvina (Micropogonias furnieri) com $56 \%$, equivalente a $1.239 \mathrm{~kg}$, seguida da Miraguaia (Pogonias cromis) com 23\% e o Bagre Netuma barba com 19\%. Em termos de biomassa, esses animais contribuíram com um equivalente próximo a $2.000 \mathrm{~kg}$ de material orgânico na quadrícula analisada.

Tabela 2 - Valores e porcentagens de NISP e MNI por níveis e por classe. Quadrícula 49.30, Sítio PT-02 Cerrito da Sotéia

\begin{tabular}{lcccc}
\hline Classe & NISP Total & \% & MNI p/níveis & \% \\
\hline Aves & 486 & 0,69 & 7 & 0,29 \\
Bivalvia & 8129 & 11,51 & 1345 & 54,88 \\
Gastropoda & 355 & 0,50 & 100 & 4,08 \\
Malacostraca & 12712 & 18,00 & 164 & 6,69 \\
mammalia & 859 & 1,22 & 94 & 3,84 \\
Osteichthyes & 48065 & 68,05 & 727 & 29,66 \\
Reptilia & 30 & 0,04 & 14 & 0,57 \\
Total & 70636 & 100,00 & 2451 & 100,00 \\
\hline
\end{tabular}

Fonte: Adaptada de Ulguim (2010, p. 102).

Interpretação funcional do contexto arqueológico

Do ponto de vista funcional, segundo Loureiro (2008), o cerrito PT-02 foi interpretado como uma área de descarte de materiais de uma pequena área habitacional; afinal, conforme a topografia demonstrou, no entorno do montículo central há suaves elevações (microrrelevos) indicativas. Além disso, segundo Ulguim (2010), a grande quantidade 
de fauna lacustre evidenciada em todos os níveis estratigráficos indica que o espaço fosse utilizado também como acampamento de pesca lacustre. É possível pensar, também, conforme apontam Garcia e Milheira (2011), que o montículo tenha sido um espaço de ocupação multifuncional utilizado tanto como área de pesca e processamento de recursos lacustres, como espaço de moradia, ocupado e utilizado por um período não muito extenso, devido ao horizonte cronológico indicado pelas datações calibradas.

\section{Complexo de cerritos do Pontal da Barra}

\section{Breve descrição da área de implantação do sítio}

O Pontal da Barra corresponde a uma extensão da praia do Laranjal, localizada no litoral do município de Pelotas/RS. É um banhado localizado na barra, à margem direita da Laguna dos Patos e a margem esquerda do canal São Gonçalo. Configura-se como uma ponta de areias quartzosas em área composta por neossolo quartzarênico. A cobertura vegetal predominante no Pontal da Barra é composta basicamente por uma vegetação paludosa típica de banhados, que pode ser descrita como uma formação pioneira dominada por ciperáceas, conhecidas popularmente por juncais. Além disso, no banhado do pontal ocorrem alguns capões de mata nativa em avançado grau de degradação, uma vez que é muito comum a exploração das mudas nativas para comercialização por membros da comunidade local, assim como lenhas e outros tipos de plantas para jardins.

O banhado funciona como um lago de inundação da várzea do canal São Gonçalo e da Laguna dos Patos, causando um "efeito esponja". É uma área de controle hidrológico, reservatórios de água, acúmulo de nutrientes e habitat de uma grande variedade de espécies típicas do ambiente pampeano. No pontal, além do ambiente paludoso de banhados, encontra-se o resquício meridional da mata atlântica sobre um cordão de paleodunas, o que confere ao Pontal da Barra um caráter ecótono de alta diversidade e sensibilidade ambiental (SELMO;
ASMUS, 2006). Da mesma forma como ocorre na lagoa do Fragata, é sobre albardões que ocorrem os sítios do Pontal da Barra, também com variações de altimetria entre 4 e 6 m.s.n.m.

É importante mencionarmos que o banhado do Pontal da Barra é foco de um projeto imobiliário que busca a construção de um loteamento residencial. Esse projeto vem sendo criticado por patrimonialistas e ambientalistas em um movimento chamado Pontal Vivo desde os anos 1990 devido à grande ameaça que significa ao patrimônio natural e cultural (NEBEL, 2014; MILHEIRA, 2015). Além dos sítios arqueológicos, o movimento busca a preservação do banhado do Pontal da Barra e de toda a sua diversidade de fauna e flora, suas mais de 500 espécies de animais, alguns deles em ameaça grave de extinção, como é o caso dos peixes anuais - Austrolebias nigrofasciatus e Austrolebias wolterstorff (MAURICIO; DIAS, 2000). O banhado do Pontal da Barra, atualmente, tem uma parte ocupada por pescadores tradicionais na área denominada Barra. Além disso, ocorre criação de pecuária e há uma pequena ocupação que habita nas áreas de mata. Além disso, o banhado é uma área de caça ilegal e de lazer de moradores da praia do Laranjal (NEBEL, 2014).

\section{Intervenções realizadas e descrição dos sítios}

$\mathrm{Na}$ área do banhado do Pontal da Barra houve um investimento de pesquisa mais intensivo até o momento, que iniciou com o mapeamento de 18 sítios, a partir do ano de 2006, e intervenções arqueológicas pontuais, iniciadas em 2010.

No montículo PSG-01, o trabalho arqueológico se limitou à retificação de um perfil com 3,35 m, localizado na zona norte, o qual tem um plano de $22 \mathrm{~m}$ no eixo norte-sul, $28 \mathrm{~m}$ no eixo leste-oeste e 0,6 $\mathrm{m}$ de altura com um total de $113 \mathrm{~m}^{2}$. A coleção arqueológica é composta por 231 fragmentos cerâmicos, 31 materiais líticos, 38 ossos humanos e $2.518 \mathrm{~kg}$ de restos arqueofaunísticos.

O cerrito PSG-02 tem um formato elíptico medido de maneira imprecisa por conta do efeito da extração ilegal de sedimento na zona leste do sítio por membros da comunidade local. Entretanto, a 
matriz original deveria ter um eixo norte-sul com $46 \mathrm{~m}$, um eixo leste-oeste com $29 \mathrm{~m}$ e altura de 1,15 $\mathrm{m}$, comum uma área de $140 \mathrm{~m}^{2}$ aproximadamente. No topo do montículo, foi escavado um grid de três quadras de $1 \mathrm{~m}^{2}$ cada. No oeste do sítio, na meia encosta, foram escavadas três quadras, formando um “T”, somando $2 \mathrm{~m}^{2}$. Também foram feitas sondagens com 0,5 de lado no leste e norte do sítio. Além disso, foi feita a retificação de um perfil com $6,5 \mathrm{~m} \mathrm{x} \mathrm{1,2} \mathrm{m}$ de profundidade na zona leste do montículo. Foram coletados ao todo 1.220 fragmentos cerâmicos, 112 materiais líticos, 44 ossos humanos e $26.746 \mathrm{~kg}$ de vestígios arqueofaunísticos.
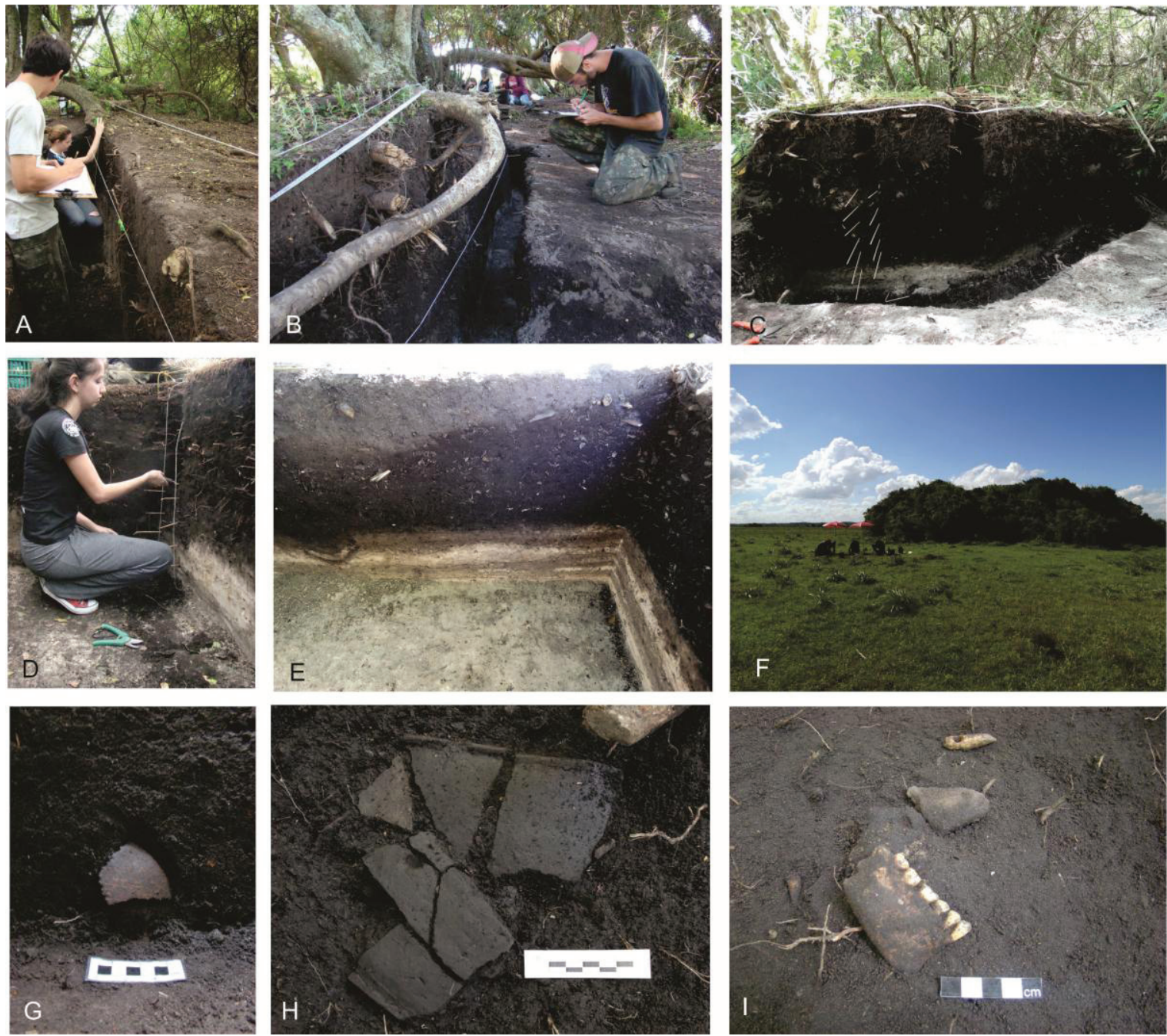

Figura 4 - A) perfil retificado do sítio PSG-01; B) perfil retificado do sítio PSG-02; C) perfil retificado do PSG-03 e coleta de amostras de solo em colunas; D) perfil retificado no PSG-06 e coleta de amostras de solo em colunas; E) perfil leste do sítio PSG-07 apresentando contraste entre o solo antropogênico (preto) e o solo natural do banhado (cinza claro); F) visão panorâmica da escavação arqueológica no PSG-06; G) fragmento de calota craniana próximo à base do cerrito PSG-02; H) Fragmentos cerâmicos coletados no PSG-07; I) parte de mandíbula humana associada a fragmentos cerâmicos e um pingente em dente de golfinho.

O cerrito PSG-03 também foi fortemente afetado pela extração ilegal de sedimento e sua delimitação é imprecisa. Pode-se apontar que o montículo tem formato elíptico com aproximadamente $75 \mathrm{~m}$ de extensão no eixo nortesul, $41 \mathrm{~m}$ no eixo leste-oeste e $1 \mathrm{~m}$ de altura, com uma área de aproximadamente $307 \mathrm{~m}^{2}$. Foram feitas duas retificações de perfis, um com 2,4 m de extensão e o outro com 2,3 m de extensão, ambos localizados na zona sul do sítio. A coleção arqueológica é composta por 132 fragmentos cerâmicos, seis materiais líticos e $6.492 \mathrm{~kg}$ de materiais arqueofaunísticos. 
O cerrito PSG-06 é o mais proeminente no complexo que compõem o PSG-02, PSG-05, PSG-06 e PSG-07 não por conta de sua altura, mas por ter uma plataforma alongada que se estende ao sul do sítio, a qual foi interpretada como um microrrelevo. O montículo tem um formado elíptico com aproximadamente $47 \mathrm{~m}$ no eixo norte-sul, $30 \mathrm{~m}$ no eixo leste-oeste e $1 \mathrm{~m}$ de altura, com uma área de aproximadamente $140 \mathrm{~m}^{2}$. No topo do montículo, foi feito um grid com três quadras de $1 \mathrm{~m}^{2}$ e foi escavada uma quadra de $1 \mathrm{~m}^{2}$ na área adjacente ao sul. $\mathrm{Na}$ área externa ao montículo, foi feita mais uma trincheira de $3 \mathrm{~m}^{2}$. A coleção arqueológica é composta por 801 fragmentos cerâmicos, 91 materiais líticos, três ossos humanos e $15.296 \mathrm{~kg}$ de vestígios arqueofaunísticos.

O cerrito PSG-07 tem um formato circular com aproximadamente $36 \mathrm{~m}$ no eixo norte-sul, $3 \mathrm{~m}$ no eixo leste-oeste e altura de 1,15 m, com uma área de $130 \mathrm{~m}^{2}$. A escavação foi feita no topo do montículo limitando-se a três quadras de $1 \mathrm{~m}^{2}$ cada. A coleção arqueológica é composta por 864 fragmentos cerâmicos, 47 materiais líticos, quatro ossos humanos e $30.750 \mathrm{~kg}$ de vestígios arqueofaunísticos.

Nesses seis sítios escavados, foram realizadas 24 datações radiocarbônicas, apontando que a ocupação do Pontal da Barra ocorreu provavelmente entre aproximadamente 2.000 anos $^{3}$ A.P. (conforme datação calibrada do cerrito PSG-07), até, pelo menos, 1.000 anos A.P. (conforme datação do cerrito PSG-02), sugerindo ser uma ocupação indígena bastante antiga e permanente, a qual perdurou durante aproximadamente 1.000 anos. As 24 datações foram feitas em três laboratórios distintos, sendo três amostras processadas no Center for Applied Isotope Studies da University of Georgia (UGAMS), quatro amostras no Beta Analytic labs (BETA) e 17 amostras no Radiocarbon Laboratory da Universidade Federal Fluminense (LACUFF) (ver quadro de datações na Tabela 3).

Tabela 3 - Quadro de datações dos cerritos PSG-01, PSG-02, PSG-03, PSG-06 e PSG-07 localizados no Pontal da Barra contendo informações de ID da amostra, profundidade, data convencional e modelada e material da amostra de cada uma das amostras medidas. Calibração feita por Kita Macario com OxCal v4.2.4 (BRONK RAMSEY, 2009; BRONK RAMSEY, C.; LEE, 2013) usando a curva Marine13 (REIMER et al., 2013) para otólitos e curva atmosférica SHCal13 (HOGG et al., 2013) para amostras de carvão e colágeno (MILHEIRA et al., 2017)

\begin{tabular}{|c|c|c|c|c|c|c|c|c|}
\hline & \multirow[t]{2}{*}{ Amostra ID } & \multirow[t]{2}{*}{$\begin{array}{c}\text { Profundidade } \\
(\mathrm{cm})\end{array}$} & \multirow[t]{2}{*}{$\begin{array}{c}\text { Convencional }{ }^{14} \mathrm{C} \\
\text { age }(\mathrm{BP})\end{array}$} & \multirow[t]{2}{*}{ Material } & \multicolumn{4}{|c|}{ Modelagem (BP) } \\
\hline & & & & & $(2 \sigma) \mathrm{de}$ & $(2 \sigma)$ até & $\mu$ & $\sigma$ \\
\hline \multirow{8}{*}{ PSG-07 } & BETA-415598 & 2.5 & $1720 \pm 30$ & $\begin{array}{l}\text { Osso de ca- } \\
\text { chorro }\end{array}$ & 1700 & 1530 & 1610 & 50 \\
\hline & LACUFF-140396 & 5.0 & $1696 \pm 28$ & Otólito & 1790 & 1330 & 1540 & 110 \\
\hline & LACUFF-13052 & 22.5 & $2340 \pm 150$ & Otólito & 2540 & 1360 & 1880 & 330 \\
\hline & LACUFF-140393 & 42.5 & $1214 \pm 22$ & Otólito & 1730 & 870 & 1250 & 250 \\
\hline & LACUFF-140394 & 57.5 & $1660 \pm 190$ & Carvão & 1920 & 1180 & 1550 & 170 \\
\hline & LACUFF-140395 & 57.5 & $1756 \pm 28$ & Otólito & 1860 & 1390 & 1600 & 110 \\
\hline & BETA 389013 & 67.5 & $1670 \pm 30$ & Otólito & 1750 & 1300 & 1520 & 110 \\
\hline & BETA 389014 & 82.5 & $1630 \pm 30$ & Carvão & 1570 & 1400 & 1480 & 40 \\
\hline \multirow{4}{*}{ PSG-06 } & LACUFF-13053 & 2.5 & $1480 \pm 130$ & Otólito & 1630 & 1030 & 1330 & 140 \\
\hline & LACUFF-140392 & 12.5 & $1355 \pm 37$ & Otólito & 1440 & 990 & 1220 & 100 \\
\hline & LACUFF-13055 & 32.5 & $1548 \pm 59$ & Otólito & 1620 & 1170 & 1380 & 110 \\
\hline & LACUFF-13054 & 60 & $1652 \pm 33$ & Otólito & 1710 & 1260 & 1470 & 110 \\
\hline PSG-03 & BETA-389011 & 85 & $1490 \pm 30$ & Otólito & 1550 & 1140 & 1320 & 100 \\
\hline \multirow{8}{*}{ PSG-02 } & UGAMS-12060 & 2.5 & $1390 \pm 20$ & Osso humano & 1310 & 1270 & 1290 & 10 \\
\hline & UGAMS-12061 & 2.5 & $1590 \pm 20$ & Otólito & 1650 & 1250 & 1420 & 100 \\
\hline & LACUFF-13056 & 15 & $1859 \pm 29$ & Otólito & 1970 & 1410 & 1690 & 140 \\
\hline & LACUFF-13049 & 22.5 & $1604 \pm 32$ & Carvão & 1540 & 1370 & 1450 & 50 \\
\hline & LACUFF-13050 & 35 & $1680 \pm 30$ & Carvão & 1610 & 1420 & 1530 & 50 \\
\hline & LACUFF-13051 & 50 & $1493 \pm 31$ & Carvão & 1410 & 1290 & 1340 & 30 \\
\hline & LACUFF-140391 & 75 & $1724 \pm 40$ & Otólito & 1820 & 1340 & 1570 & 120 \\
\hline & UGAMS-12062 & 77.5 & $1280 \pm 20$ & Otólito & 1460 & 920 & 1180 & 130 \\
\hline \multirow{3}{*}{ PSG-01 } & LACUFF-13058 & 7.5 & $1697 \pm 32$ & Otólito & 1810 & 1330 & 1560 & 120 \\
\hline & LACUFF-13057 & 35 & $1930 \pm 180$ & Otólito & 2130 & 1340 & 1710 & 200 \\
\hline & LACUFF-13059 & 50 & $1860 \pm 100$ & Otólito & 2000 & 1380 & 1680 & 150 \\
\hline
\end{tabular}


Os trabalhos de mapeamento, microtopografia e levantamento de estruturas arqueológicas em subsolo com uso de georadar apontaram a existência de estruturas arqueológicas adjacentes aos cerritos. Negativos topográficos, interpretados como áreas de empréstimo para construção dos cerritos, foram detectados no entorno dos cerrito PSG-02, PSG-07 e entre os cerrito PSG-07 e PSG-05. Essas áreas têm quotas que oscilam entre 20 e $40 \mathrm{~cm}$ abaixo da superfície natural do banhado. São estruturas bem definidas, e algumas delas são perceptíveis a olho nu, já que costumam permanecer alagadas ao longo do ano, mesmo em épocas mais quentes e secas, como no verão, quando o banhado tende a estar menos cheio. Nessas áreas negativas, além da percepção topográfica, é importante ressaltarmos que foi detectada a ausência da camada sedimentar que compõem os $25 \mathrm{~cm}$ superficiais do banhado do Pontal da Barra. Trata-se de uma camada de sedimento arenoso, rico em matéria orgânica e humidade, resultante da decomposição da vegetação rasteira do banhado, o que lhe confere uma coloração cinza-escura. Por ser uma camada de sedimento mais rico em matéria orgânica, sugerimos que os construtores de cerritos privilegiaram essa camada superficial para elevação das estruturas. Soma-se a isso o fato de que as tecnologias de coleta de sedimento dessas populações talvez tenha sido um limitador, impedindo a exploração de camadas mais profundas do terreno, a exemplo das intepretações realizadas no sítio Pago Lindo, em Tacuarembó, Uruguai (VILLAGRAN; GIANOTTI, 2013).

Foram detectadas, também, estruturas em quotas positivas, denominadas na literatura de microrrelevos e interpretadas como espaços de moradia adjacentes aos cerritos. $\mathrm{O}$ microrrelevo mais evidente compõe uma suave plataforma ao sul do cerrito PSG-06, cuja planificação pode ser percebida a olho nu. Esse plano é composto por uma camada de sedimento semelhante ao que compõe os cerritos, com as mesmas características granulométricas, de textura e coloração; porém, com uma frequência menor de artefatos como cerâmicas e materiais líticos (MÜHLEN, 2014).

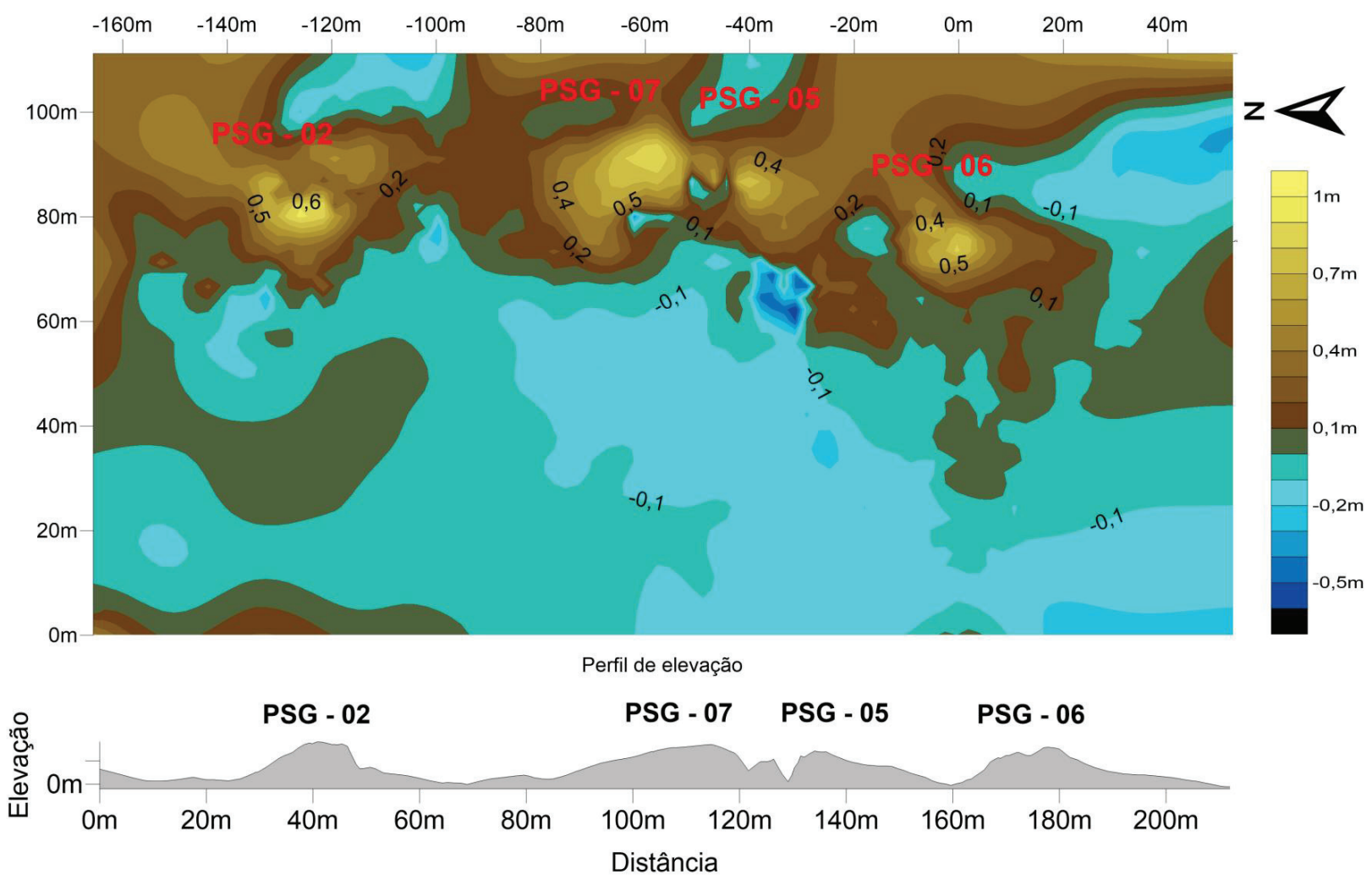

Figura 5 - Mapa topográfico em 2D e perfil topográfico do conjunto de cerritos PSG-02, PSG-05, PSG-06 e PSG-07, indicando as áreas de empréstimo, o microrrelevo e as quadras de escavação dos cerritos, com destaque para a escavação da paleodrenagem (quadra em preto) adjacente ao cerrito PSG-06 Fonte: Elaborada por Cleiton Silveira. 


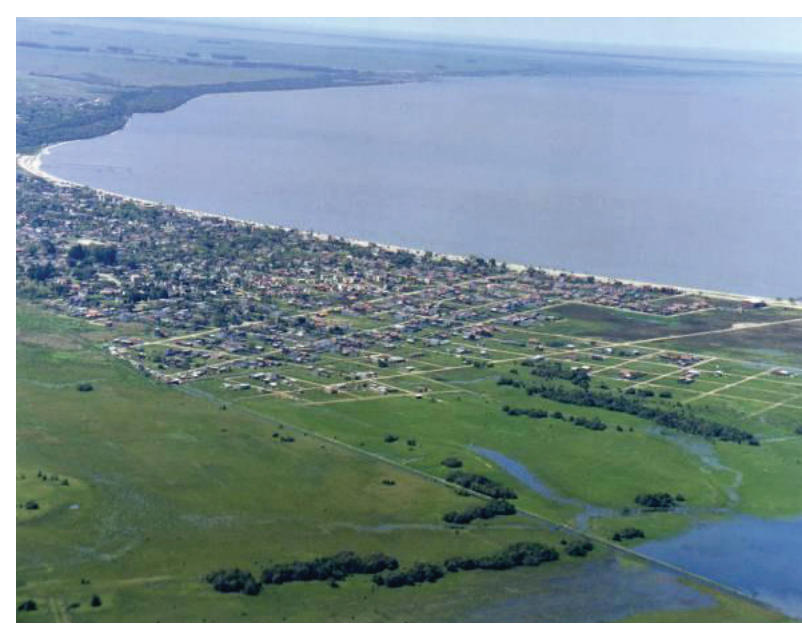

Figura 6 - Imagem aérea do Pontal da Barra em épocas de cheia com a localização das matas sobre albardões, foto retirada de Selmo e Asmus (2006) Fotos: Acervo LEPAARQ/UFPel.

É interessante notar também os altos índices de fósforo em todas as camadas dos cerritos que tiveram amostras de solo analisadas desde um ponto de vista químico (ver Tabela 4). Foram comparadas amostras de solo dos cerritos PSG-02 e PSG-06 e de uma área natural do banhado (sondagem externa), apontando resultados que são gritantemente diferentes e que apontam para um enriquecimento antrópico dos cerritos, sendo um elemento a mais na hipótese de que os cerritos sejam construções feitas pela mão humana (TEIXEIRA et al., 2010).

Tabela 4 - Dados referentes aos dados de fósforo (P-Mielich) analisados nos cerritos PSG-02, PSG-06 e área natural externa aos cerritos. Os valores são apresentados $\mathrm{em} \mathrm{mg} / \mathrm{dm}^{3}$

\begin{tabular}{cccc}
\hline Profundidade & $\begin{array}{c}\text { Sondagem } \\
\text { externa }\end{array}$ & PSG-02 & PSG-06 \\
\hline $0-10 \mathrm{~cm}$ & 10,6 & 338,5 & 188,2 \\
$10-20 \mathrm{~cm}$ & 3,5 & 345,5 & 178,8 \\
$20-30 \mathrm{~cm}$ & 1,8 & 371,2 & 156,8 \\
$30-40 \mathrm{~cm}$ & 4,4 & 354,9 & 159,9 \\
$40-50 \mathrm{~cm}$ & 4,4 & 259,1 & 131,7 \\
$50-60 \mathrm{~cm}$ & $\mathrm{x}$ & 319,5 & 150,5 \\
$60-70 \mathrm{~cm}$ & $\mathrm{x}$ & 211,8 & 169,4 \\
$70-80 \mathrm{~cm}$ & $\mathrm{x}$ & 300,1 & 100,9 \\
$80-90 \mathrm{~cm}$ & $\mathrm{x}$ & 270,8 & $\mathrm{x}$ \\
$90-100 \mathrm{~cm}$ & $\mathrm{x}$ & 229,5 & $\mathrm{x}$ \\
\hline
\end{tabular}

\section{Tecnologia cerâmica}

Até o presente momento, foram realizados estudos de tecnologia cerâmica nos sítios PSG-03, PSG-04 e PSG-07, os quais serão descritos em conjuntos para síntese das coleções, cujos dados podem ser acessados em Ribeiro e Milheira (2015). No total, foram analisados 839 fragmentos cerâmicos: 132 que compõem a coleção do sítio PSG-03, e 81 que compõem a coleção do PSG-04, ambas analisadas integralmente; e 626 fragmentos que compõem a coleção PSG-07, da qual foram analisadas apenas os fragmentos maiores que $2 \mathrm{~cm}$, devido à alta taxa de fragmentação verificada nesta amostra.

A técnica de confecção predominante nas coleções éa roletada, e a queima é predominantemente incompleta, com tendência à redutora. Apenas 247 fragmentos (29\% do total analisado) apresentaram indícios de queima oxidada. Quanto à secção, os fragmentos analisados podem ser classificados em 661 paredes, 146 bordas e 32 bases, embora ocorram peças que foram remontadas e que apresentam duas secções.

A variabilidade morfológica verificada para os vasilhames da coleção limita-se a vasilhas abertas, fechadas e paralelas, a exemplo das formas da coleção do cerrito da Sotéia PT-02, também em proporções similares. As únicas diferenças dignas de nota são a ausência, nas coleções Pontal da Barra, de "miniaturas" e a verificação de vasilhames muito abertos, do tipo "prato/tigela". As dimensões dos vasilhames projetados $(n=28)$ variaram entre $22 \mathrm{e}$ $36 \mathrm{~cm}$ de diâmetro, reportando a vasilhas medianas.

Apesar de realmente ter sido verificada uma baixa variabilidade no que diz respeito à morfologia dos vasilhames, e nenhuma novidade no que se refere aos antiplásticos utilizados para confecção das vasilhas, predominantemente grãos de areia quartzosa de diferentes espessuras, além de materiais ferruginosos e conchas moídas, cuja grande diversidade é naturalmente encontrada nos bancos de argila e pode apontar para uma não seleção da granulometria desse material, um olhar mais atento tem revelado o envolvimento de argilas diferentes e grande variedade de tratamentos de superfície no bojo técnico dessa indústria cerâmica, o que parece pôr em xeque a ideia de homogeneidade tecnológica amplamente divulgada quando se lê sobre a "cerâmica Vieira" (RIBEIRO; MILHEIRA, 2015). 


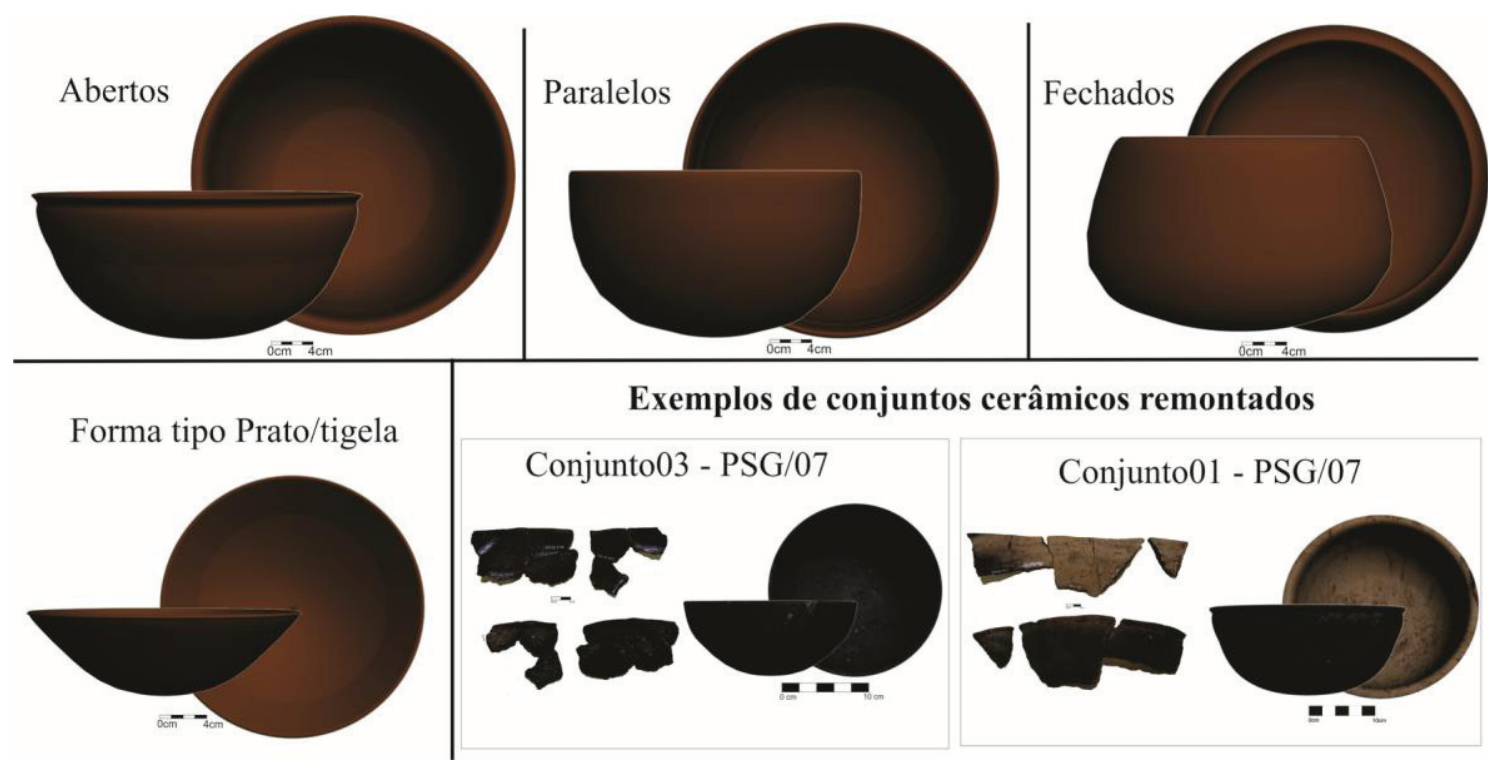

Figura 7 - Quadro com a variabilidade de formas as vasilhas cerâmicas e exemplos de conjuntos cerâmicos identificados

Fonte: Adaptada de Ribeiro e Milheira (2015, p. 108).

Não menos que cinco tipos distintos de argilas foram verificados e mais de dez tipos diferentes de tratamentos de superfície, desde os alisamentos mais grosseiros a finos polimentos, alisamentos com estrias irregulares e alisamentos finos com estrias extremamente regulares, e que, por sua vez, apontam para o envolvimento de uma série de instrumentos distintos nesta etapa da confecção dos vasilhames, além, é claro, de casos pontuais que parecem ser combinações entre tais técnicas e instrumentos. Dada a grande variabilidade de tratamentos de superfície verificados, optamos por agrupá-los em dois grandes tipos: simples e compostos, e suas frequências de aplicação podem ser mais bem representadas nos gráficos a seguir:

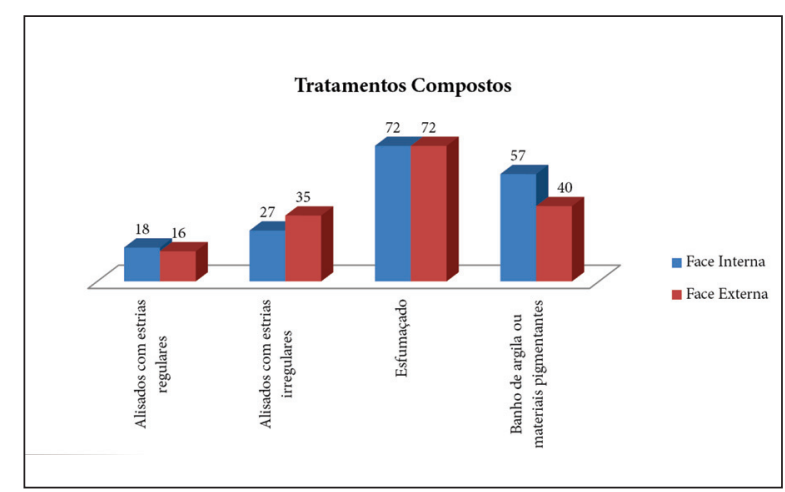

Gráficos 1 e 2 - Tratamento de superfície simples e tratamento de superfície composto Fonte: Elaborados por Bruno Leonardo Ricardo Ribeiro.

Nesse quesito, um aspecto que nos chamou atenção foi a recorrência de superfícies "banhadas" (designação sob a qual englobamos tratamentos como a barbotina, o banho de argila e o engobo que não nos pareceu demandar seu tratamento como um "caso à parte" uma vez que não foram verificadas aplicações de motivos pintados), que envolveriam a inserção de mais uma etapa nesta cadeia de produção e demandaria o preparo de outra "pasta", mais líquida, a ser despejada sobre o vasilhame, garantindo-lhe uma superfície de coloração e textura diferenciada, se comparada com as superfícies "originais" dos cacos. 


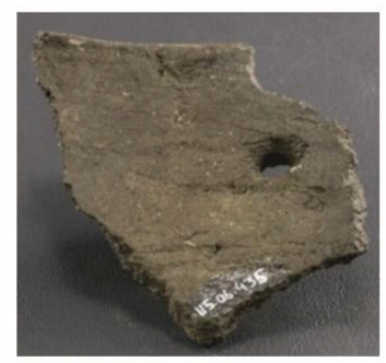

$0 \mathrm{~cm} \quad 2 \mathrm{~cm}$

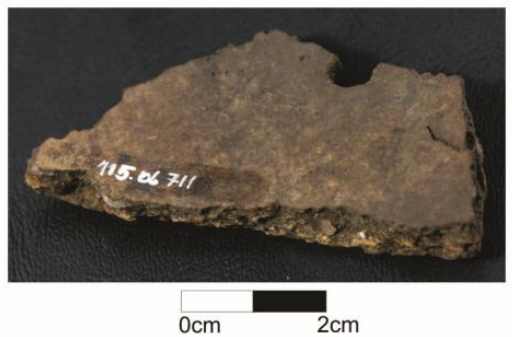

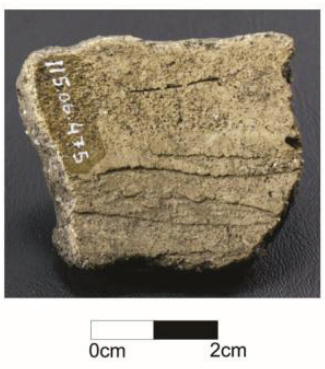
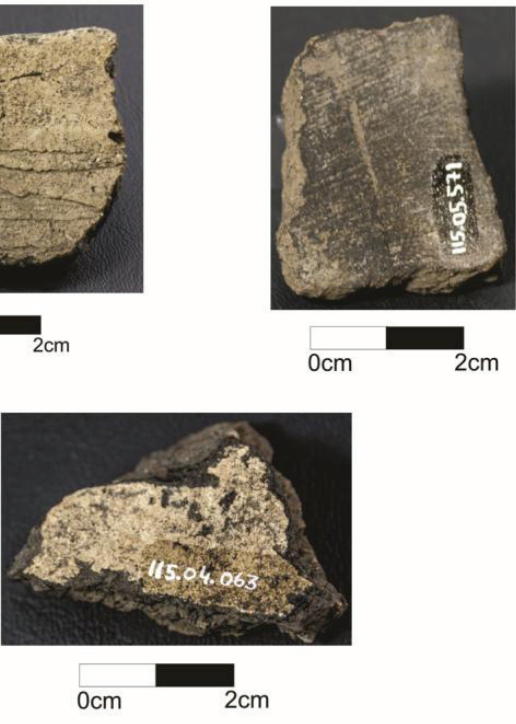
$\mathrm{cm}$

Figura 8 - Fragmentos com tratamentos de superfície variados, apontando a heterogeneidade nas técnicas Fonte: Elaborada por Bruno Leonardo Ricardo Ribeiro.

Finalmente, no campo das decorações plásticas o que chamou nossa atenção foi a recorrência de um tipo de decoração verificado até então apenas na coleção PSG-07, mas que vem sendo encontrado, também, em alguns lotes da coleção PSG-06, atualmente em análise, e tem aplicação restrita ao lábio dos vasilhames. Aparentemente, após a aplicação de um rolete extra sobre o lábio, provavelmente a partir da face interna do vasilhame, uma porção sobressalente seria "dobrada" para baixo, em direção à base do vasilhame e ao longo de sua porção externa, para posteriormente ser modelada como uma saia ou "babado". As porções superiores dos vasilhames, vale ressaltarmos, parecem ter sido as zonas de maior dedicação dos artesãos responsáveis pela coleção do Pontal da Barra: as pouquíssimas ocorrências $(n=28)$ de decorações plásticas "tradicionais" identificadas, como o digitado ou o pseudo-ungulado, foram verificadas, em sua maioria, em fragmentos de borda (RIBEIRO; MILHEIRA, 2015).
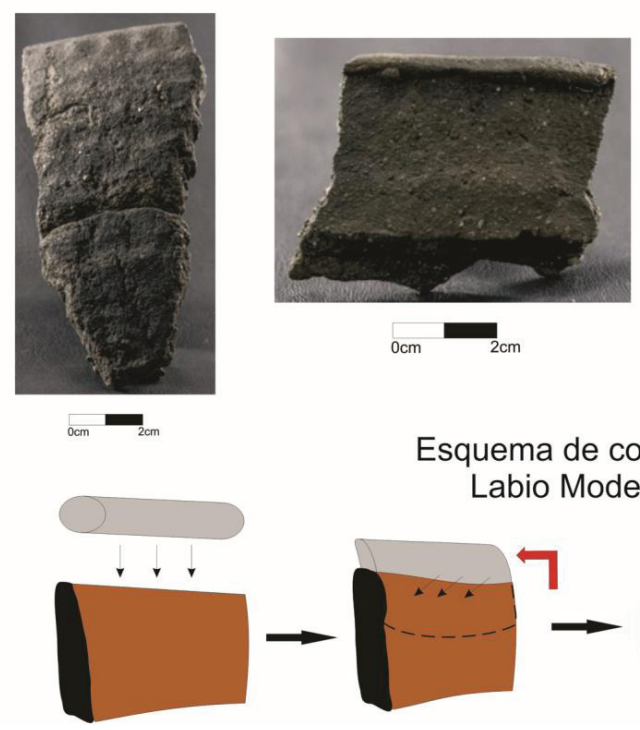

Ocm

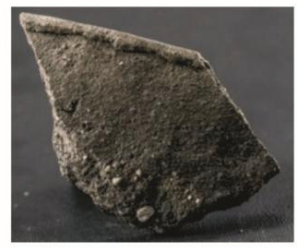

ocm $\quad 2 \mathrm{~cm}$

Esquema de confecção Labio Modelado

Figura 9 - Exemplares de bordas decoradas. À esquerda, borda com decoração digitada; à direita, bordas em que foram identificadas a aplicação do lábio "modelado". Abaixo, esquema de confecção dessa decoração Fonte: Adaptada de Ribeiro e Milheira (2015, p. 116). 


\section{Tecnologia Lítica}

No que se refere à tecnologia lítica, os instrumentos provenientes do Pontal da Barra atingem uma soma de 297 objetos encontrados em sete dos 18 sítios que receberam atividades de pesquisa. Esses materiais estão distribuídos em: 31 peças no cerrito PSG01, 100 peças no PSG02, sete peças no PSG03, nove peças no PSG04, uma peça no PSG05, 95 peças no PSG06 e peças 54 no PSG07. Essas amostras da indústria lítica são predominantemente compostas por artefatos de quartzo e granito, bem como por fragmentos da produção e uso desses instrumentos no sítio, entre os quais 164 peças são de quartzo; 128 de granito; dois de riolito; um de arenito friável; um de basalto e um de uma matéria-prima indeterminada.

Entre essas matérias-primas, foi identificada uma série de tecnotipologias líticas, onde as lascas bipolares e os resíduos angulosos da talha bipolar se mostraram numericamente muito superiores aos demais identificados, sendo contabilizadas 125 lascas bipolares e 121 resíduos. Na sequência desses, a maior representatividade quantitativa foi de instrumentos com depressão semiesférica com um total de dez, seguida por uma série de tipos que não atingiram uma dezena de exemplares.

Apresentam-se brevemente algumas características de dois exemplares de artefatos produzidos e ou utilizados pelos habitantes do Pontal da Barra. Vê-se, na Figura 10, um alisador de arenito friável do cerrito PSG-03 (a) com uma unidade transformativa em sulco (seta vermelha) em um dos lados do objeto, assim como uma possível porção proximal de lâmina de machado de basalto do cerrito PSG-04 (b), com parcela da parte preensiva indicada pela seta vermelha. O tracejado em sua porção distal indica a área de uma fratura latitudinal.
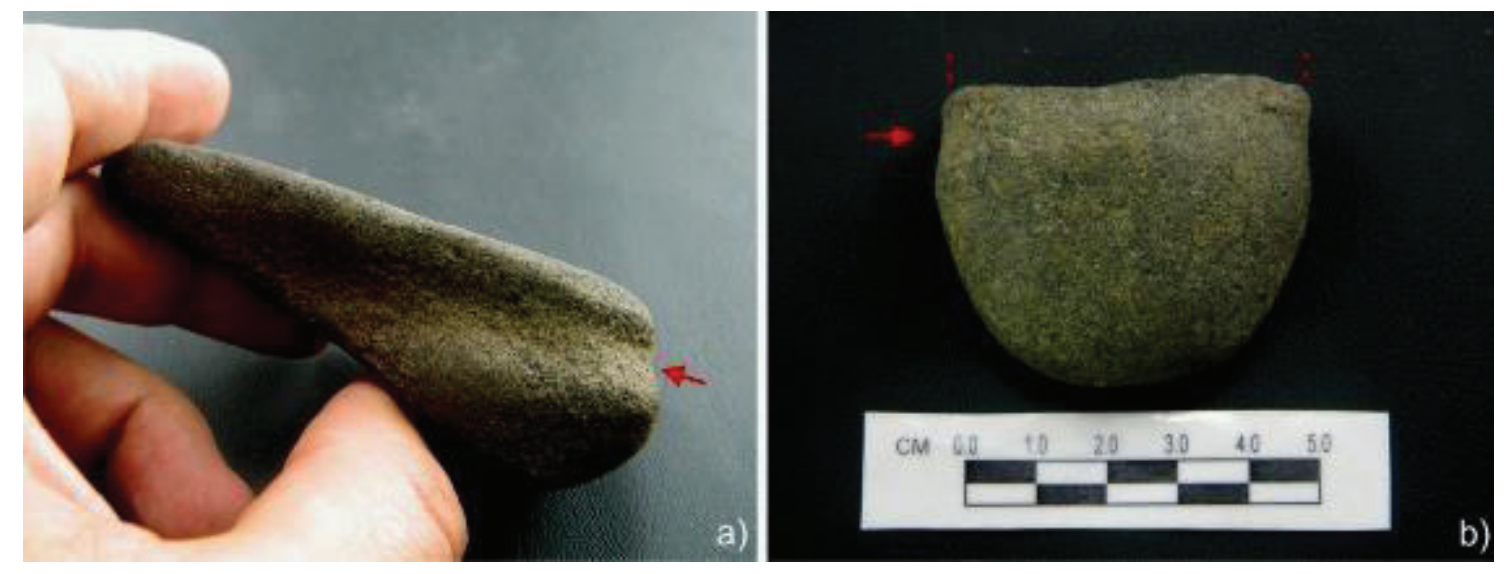

Figura 10 - a) alisador; b) possível porção proximal de lâmina de machado Fotos: Anderson Marques Garcia.

\section{Interpretação funcional do contexto arqueológico}

Os cerritos do Pontal da Barra já estudados apontam para uma construção como plataformas elevadas para moradia em ambientes alagados, visto que se localizam em áreas topograficamente mais elevadas. Porém, a função dessas estruturas de aterro não se limitava apenas a moradias. A análise química do sedimento dos cerritos PSG-02 e PSG-06 apontou um grande potencial agrícola dos montículos, típico das “Terras pretas de Índio", comumente identificadas e discutidas em contexto amazônico, o que se soma aos estudos iniciais de arqueobotânica já realizados, que permitiram a identificação de plantas que talvez fossem manejadas, como a presença de amidos de Poaceae, que podem ser indícios de milho (Zea mays), encontrados no sedimento dos cerritos PSG-01 (SOARES, 2014). Um dado interessante é que há uma inversão estratigráfica do cerrito PSG-02, em que a base (1.280 \pm 20 A.P, protocolo UGAM-12062) do montículo apresentou uma data radiocarbônica mais jovem que o topo $(1.590 \pm 20$ A.P, protocolo UGAM-12061). Essa é uma questão 
arqueológica importante que remete à hipótese de o montículo ter sido utilizado como área de plantio e/ou área de lixeira, compondo um "jardim", como os montículos descritos etnograficamente entre os Kuikuru (SCHMIDT; HECKENBERGER, 2009) e Assurini (SILVA, 2000) do alto Xingu, os quais produzem os montículos para uso posterior como áreas de pequenas roças domésticas, algo também apontado em cerritos do Uruguai (IRIARTE, 2006; GIANOTTI et al., 2013).

Essas interpretações iniciais, a serem mais bem elaboradas, corroboram a ideia de práticas agrícolas, como aventado no contexto arqueológico de Los Ajos, no Uruguai, onde foram encontrados vestígios botânicos de milho, feijão, amendoim, batata doce, abóbora e sementes de um narcótico chamado chamico (IRIARTE, 2006; LOPEZ MAZZ; BRACCO, 2010; BRACCO; DEL PUERTO; INDA, 2008). Da mesma forma, reforçariam os dados de vestígios cerâmicos através de análise de partículas biosilíceas, estudo realizado pelos autores Capdepont, Del Puerto e Inda (2002, p. 8-9), que mostraram cerâmicas com vestígios de vegetais, butiá, cannanáceas, milho e corcubitáceas. No entanto, no csendoaso do Pontal da Barra, a incipiência dos dados devido ao início desse tipo de pesquisa do campo da arqueobotânica requer cautela nesse tipo de interpretação. Logo, não seria prudente, neste momento, confirmarmos a ocorrência de práticas de manejo agrícola, questão essa que é central em nossa pesquisa e que será perseguida, visto que a prática de manejo de plantas apontaria não apenas uma diversificação alimentar e econômica, mas ampliaria o olhar arqueológico para além dos sítios em si, chamando a atenção para práticas de manejo ambiental, conectando a confecção de terra preta que constituem os cerritos, resultado de compostagem orgânica, ao cultivo de botânicos e transformação de paisagens.

No entanto, se devemos ter cautela ao levantar hipóteses sobre o manejo de plantas comestíveis e sobre práticas agrícolas, os indícios de caça e pesca são bem mais evidentes e nos permitem ter clareza da importância dos animais vertebrados na dieta alimentar. Trabalhos de zooarqueologia realizados (e em andamento) demonstram que são muito frequentes vestígios ósseos de peixes da Laguna dos Patos, como Corvina (Micropogonias furnieri) e Bagre (família Ariidae) e, até mesmo, a Miraguaia (Pogonias cromis), cuja espécie era comumente encontrada na laguna até 40 ou 50 anos atrás, sendo rara sua presença na atualidade. Além disso, também no cerrito PSG-02 foi identificada uma estrutura que sugere ser uma lixeira ou uma fossa culinária. Tratase de uma estrutura composta basicamente por ossos de peixes com muita concentração de cinzas e carvões associados. Nitidamente, a escavação dessa estrutura demonstrou que o material fora depositado em uma fossa, com formato cônico, gerando, inclusive, um sedimento orgânico diferenciado.

Além de ser uma área usada para moradia com grande potencial agrícola e apresentar uma estrutura de lixeira ou fossa culinária, no cerrito PSG-02 assim como em outros cerritos do Pontal da Barra, foram escavados ossos humanos que remetem a sepultamentos secundários. Esses sepultamentos humanos denotam um aspecto simbólico, portanto, dos montículos de terra, que reforçam a ideia de que esses aterros não são apenas moradias, nem apenas acampamentos de pesca lacustre. Em nosso entendimento, é possível levantar a hipótese de que esses cerritos teriam sido utilizados para várias finalidades como áreas domésticas, de sepultamento dos mortos, deposição de lixo, possível manejo de botânicos e acampamentos de pesca lacustre.

\section{Complexo de Cerritos da Lagoa do Fragata}

\section{Breve descrição da área de implantação do sítio}

A região da lagoa do Fragata se localiza na margem direita do canal São Gonçalo, sendo abastecida também pelo deságue do arroio Moreira, desde a serra do Sudeste. Do ponto de vista geomorfológico, a paisagem se caracteriza por apresentar terrenos baixos, planos e pouco drenados, configurando extensos banhados típicos no sistema Patos-Mirim, com alturas que variam de 2 a 3 m.s.n.m. O terreno baixo e plano dos banhados é cortado por albardões (paleolinhas de praias) localizados ao longo do canal São Gonçalo e das bordas dos banhados e lagoa do Fragata, sendo os pontos com 
quotas mais altas variando entre 4 e 6 m.s.n.m. Esses sutis acidentes geográficos naturais são de formato circular e subcircular, conformando topografias positivas de origem fluvial, onde se desenvolveram horizontes húmicos pouco profundos, colonizados por gramíneas e diversas espécies arbustivas e capões de mato, que configuram uma vegetação pioneira (BRASIL, 1986).

\section{Intervenções realizadas e descrição dos sítios}

Foram identificados 11 sítios no entorno da lagoa do Fragata, várzea do canal São Gonçalo, entre os municípios de Pelotas e Capão do leão. Essa área passou a ser pesquisada devido à identificação, há mais de 30 anos, de uma coleção de materiais líticos composta por dois zoólitos, representando um tubarão branco e uma ave columbiforme, além de duas bolas de boleadeira mamilares, dois bastonetes polidos, uma lâmina de machado polida e uma mó. Esses materiais foram encontrados por moradores locais e a importância de seu achado se dá por serem peças associadas à cultura sambaquieira e aos grupos construtores de cerritos, respectivamente. Estudos sobre essas coleções encontram-se em Mentz Ribeiro et al. (2002); Milheira (2005); Gonzales e Milheira (2004).
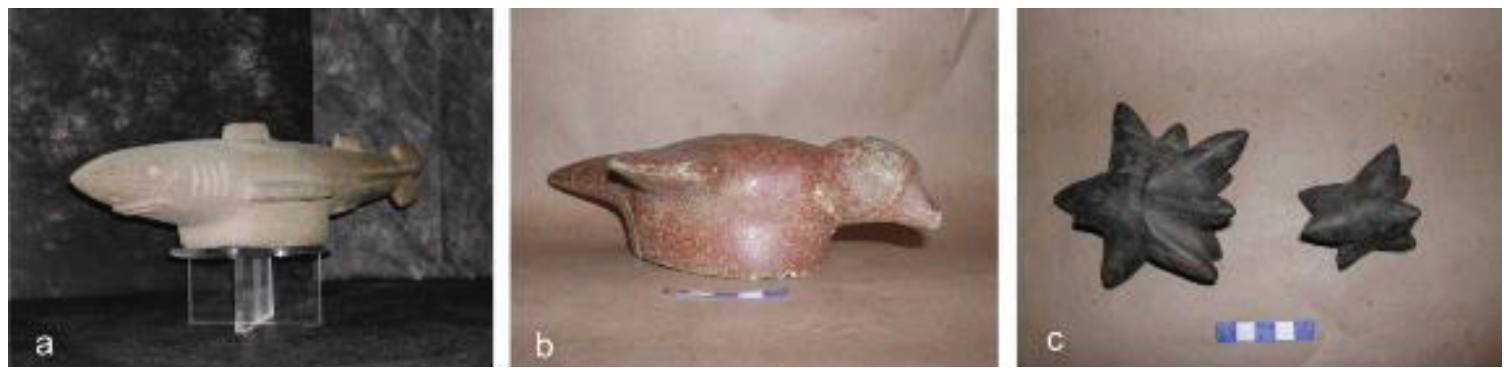

Figura 11 - Materiais que compõem coleção “Carla Rosane Duarte Costa”: a) zoólito de tubarão, b) zoólito de ave columbiforme c) bolas de boleadeiras mamilares Fotos: Acervo LEPAARQ/UFPel.

Na lagoa do Fragata, é sobre albardões naturais que ocorrem alguns dos depósitos arqueológicos identificados. E, após seu registro e mapeamento arqueológico (MILHEIRA; PEÇANHA; MÜHLEN, 2014), foram realizados poços teste e coleta de superfície de materiais arqueológicos a fim de delimitar horizontal e verticalmente as estruturas. Além disso, também foi realizado um levantamento topográfico de cada sítio com auxílio de GPS geodésico, através do método RTK (Real Time Kinematic), o que permitiu confeccionar mapas em 2D e 3D (PEÇANHA, 2014). Com esses dados, ficou evidente a existência de dois tipos de estruturas que se diferenciam pela sua morfologia: ocupações em albardões naturais sem indícios de construção e os cerritos construídos sobre albardões.

As ocupações em albardões naturais se caracterizam por depósitos arqueológicos fugazes, quase imperceptíveis a olho nu. Nessas áreas, a topografia e os poços teste demonstraram que morfologicamente os sítios são sutis elevações no terreno, oscilando entre 25 e $45 \mathrm{~cm}$, com áreas mais ou menos alongadas, que variam de 200 a $2.000 \mathrm{~m}^{2}$. A composição estratigráfica dos sítios é bastante homogênea para todos os depósitos arqueológicos. São sítios com sedimento arenoso, granulometria média a fina com presença de raízes e radículas, e bastante matéria orgânica. A coloração, conforme a escala Munsell, foi classificada em Very dark grey (7YR, 3/1, seco). Mudanças significativas na estratigrafia ocorrem somente ao final do pacote arqueológico, quando se passa de um sedimento escuro para uma composição cada vez mais clara, com matizes amarronzados (Browm, 7YR, 5/4, seco), de granulometria fina e baixa presença de matéria orgânica.

A topografia refinada e a leitura dos poços teste apontou que os sítios PSGLF-06 $(25 \mathrm{~cm}$ de altura), PSGLF-03 (25 cm de altura), PSGLF-07 (35 $\mathrm{cm}$ de altura), PSGLF-04 (40 cm de altura) e 
PSGLF-05 (40 cm de altura) são elevações muito sutis, quase imperceptíveis na paisagem. As plantas baixas destes sítios demonstram que os depósitos arqueológicos ocorrem em áreas alongadas conforme o formato dos albardões. Além disso, as sondagens realizadas nos sítios demonstraram que se trata de depósitos muito pouco profundos, com uma potência estratigráfica que raramente ultrapassa os $25 \mathrm{~cm}$ de profundidade, como pode ser visto, por exemplo, no sítio PSGLF-03 (Figura 12).

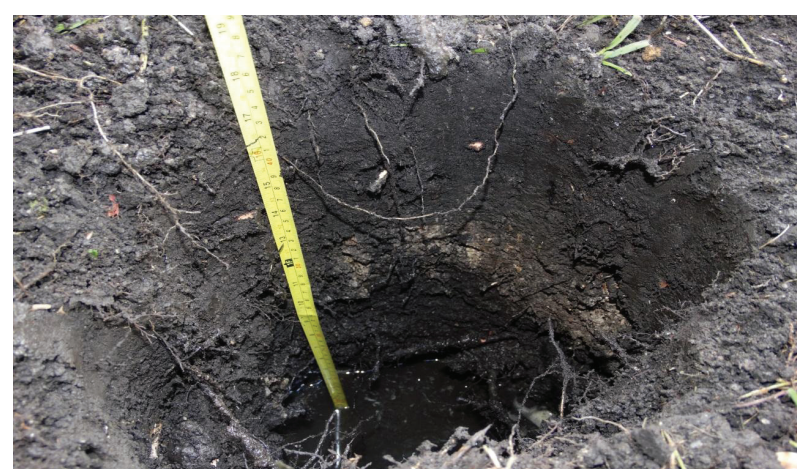

Figura 12 - Evidência de fundo de fogueira a aproximadamente 15 centímetros da face do solo Fonte: Peçanha (2014, p. 88).
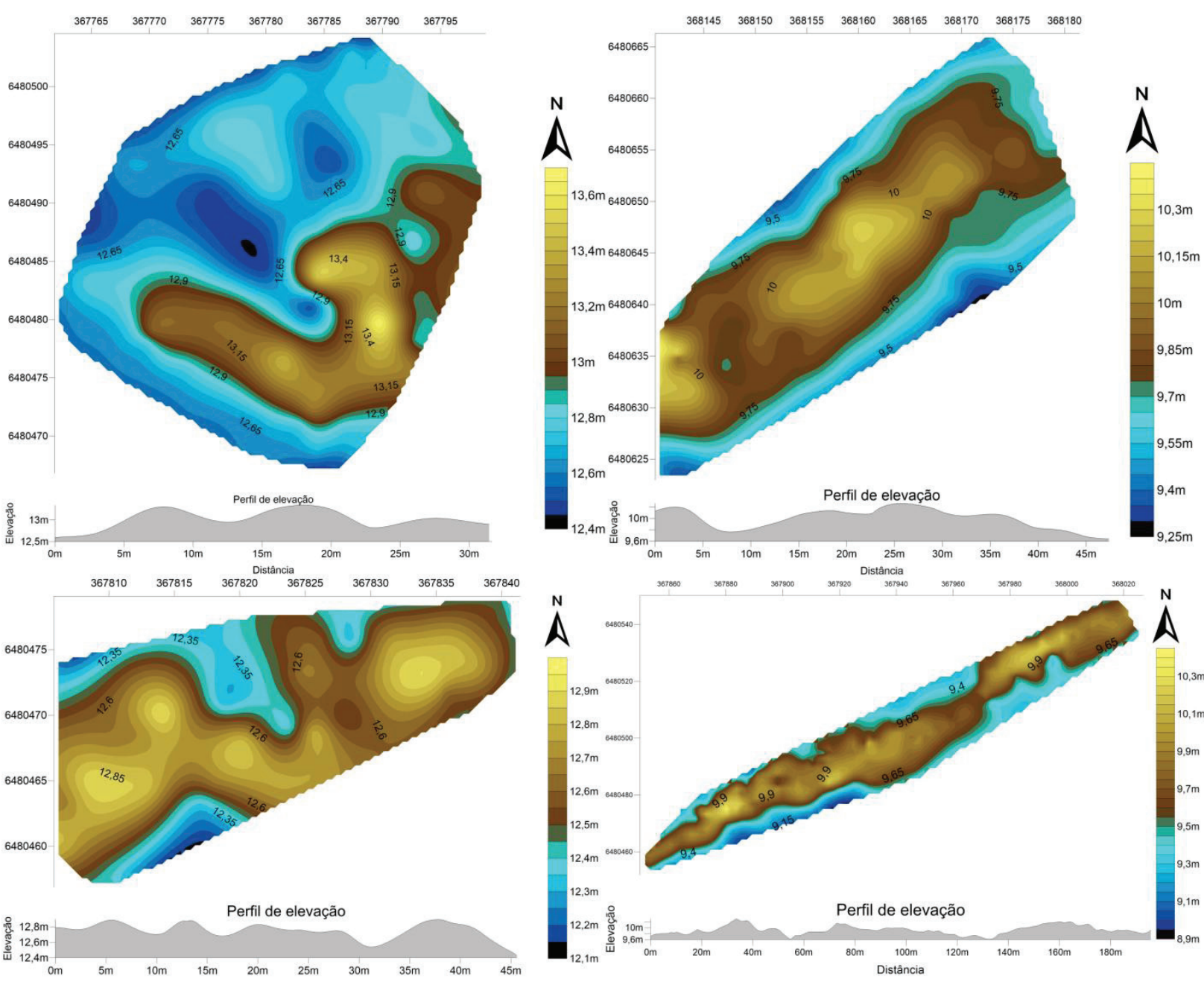

Figura 13 - Plantas dos sítios PSGLF-03, PSGLF-04, PSGLF-05 e PSGLF-07 demonstrando o formato alongado das áreas de ocupação, indicando que as áreas sejam albardões naturais ocupados, sem indícios de construção Fonte: Peçanha (2014).

Apenas três cerritos entre os mapeados na lagoa do Fragata apresentam aspectos construtivos. Morfologicamente, o cerrito PSGLF-01 é mais proeminente na paisagem com relação às demais ocupações. Apresenta uma planta de base em formato de "meia lua" e um aspecto de cômoro, com $65 \mathrm{~cm}$ de altura em relação ao solo natural do albardão sobre o qual a estrutura foi construída, tendo seu eixo maior 
com $22 \mathrm{~m}$ e eixo menor de $15 \mathrm{~m}$, configurando uma área de $205 \mathrm{~m}^{2}$. Encontramos, também, uma área bastante deprimida no centro da topografia, cuja hipótese é de que seja um negativo topográfico, embora sejam necessários estudos interventivos para tal conclusão.

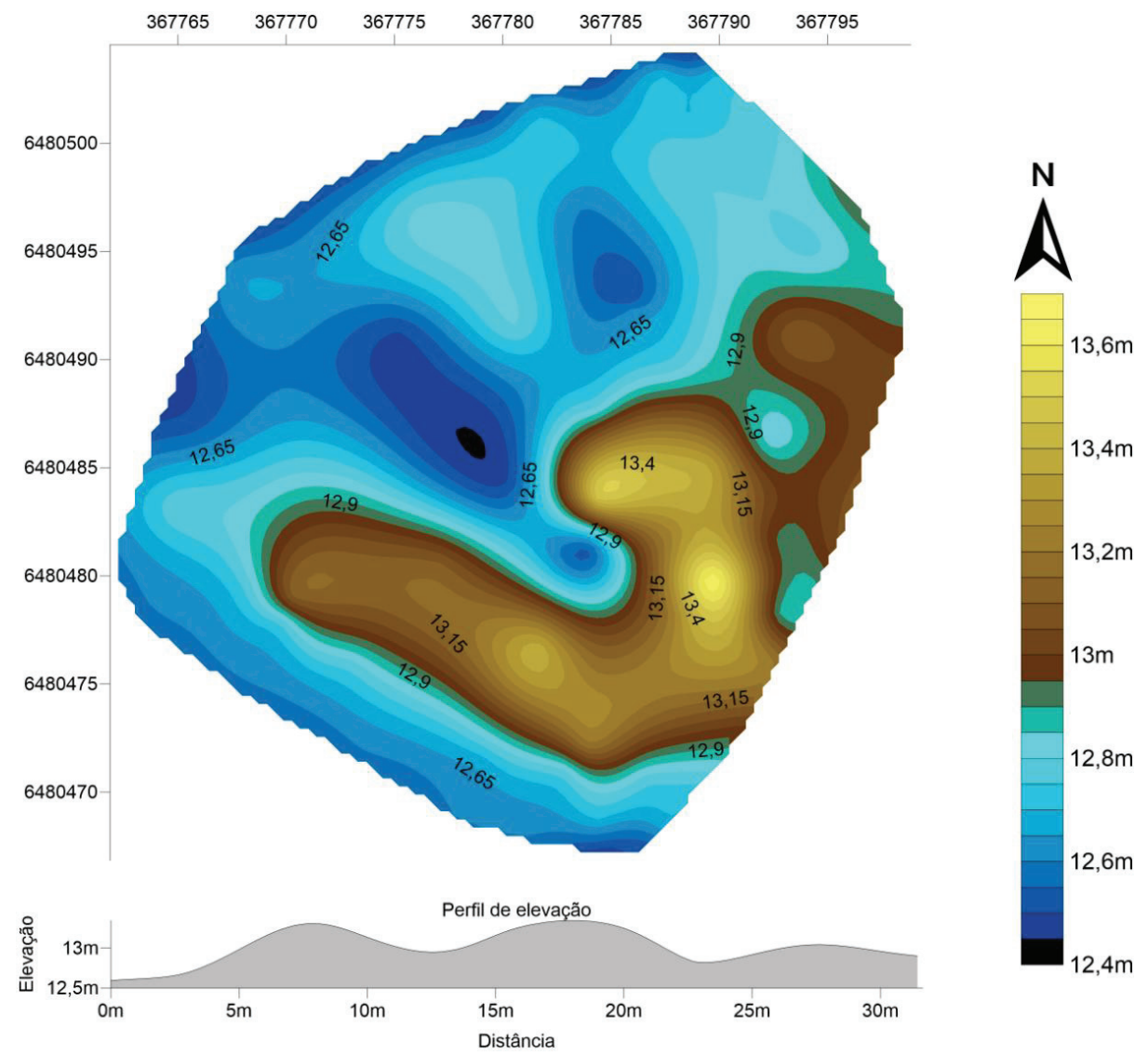

Figura 14 - Topografia do sítio PSGLF-01 apontando o formato do cerrito em "meia lua" e sua depressão adjacente. Também demonstra o perfil de elevação do sítio em escala. Escala vertical georeferenciada de acordo com o nível do mar Fonte: Elaborada por Cleiton Silveira.

O sítio PSG-20 Pavão 1, articulado ao PSG-21 Pavão 2 foi identificado no ano de 2015 durante o diagnóstico interventivo e prospecção da área de implantação de uma adutora do sistema de abastecimento de água do SANEP, Pelotas. Para identificação e delimitação, foram realizadas 18 sondagens com boca de lobo, gerando uma coleção de 238 materiais arqueológicos entre cerâmicas, líticos, fauna e botânico (VIANA; PEIXOTO, 2015). Trata-se de um sítio que também apresenta um formato de "meia lua". Localiza-se às margens do canal São Gonçalo em uma área de banhado, plana e bastante alagadiça. Nosso trabalho nesse sítio se limitou, até o momento, à realização de uma topografia refinada e à aquisição de imagens de subsuperfície com uso de GPR e eletrorresitivímetro (dados em processamento). Com base nessas poucas intervenções, podemos afirmar que o cerrito tem 92 $\mathrm{cm}$ de profundidade e sua área central, um formato complexo com $47 \mathrm{~m}$ no eixo maior (norte-sul) e eixo menor de $24 \mathrm{~m}$ (leste-oeste), configurando uma área de $5.034 \mathrm{~m}^{2}$

O cerrito PSGLF-02 localiza-se à margem da lagoa do Fragata e canal São Gonçalo em uma área de banhados. Foi identificado em trabalhos de prospecção no ano de 2010, quando a equipe do LEPAARQ fez apenas um reconhecimento superficial, identificando materiais como cerâmicas, lítico e fauna. No ano de 2014, no entanto, uma equipe de arqueologia consultiva que prospectava uma linha de transmissão elétrica também identificou o montículo, realizado uma bateria de 13 sondagens 
com uso de boca de lobo. Essa equipe sugeriu que o montículo fosse respeitado e que, além do trabalho de salvamento, fosse feito um desvio das torres para que não houvesse impactação, o que não ocorreu, pois foi construída, de forma deliberada, uma torre sobre o sítio (COPÉ, 2014).

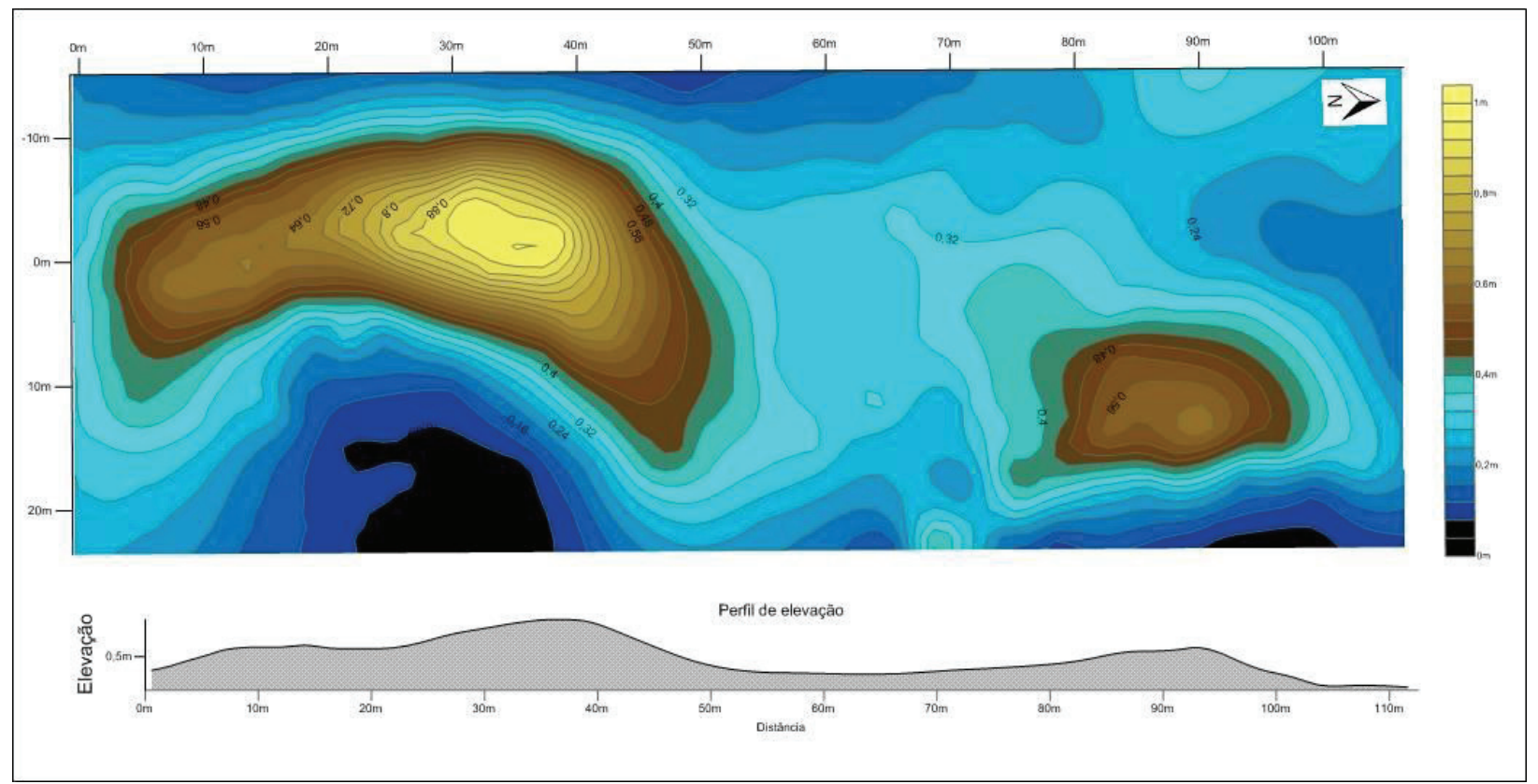

Figura 15 - Topografia dos sítios Pavão 1 (planta baixa em formato de meia lua, ao sul) e Pavão 2 (planta baixa em formato elíptico ao norte)

Fonte: Elaborada por Marcelo Sanhudo.

O sítio apresenta uma planta complexa com dois topos de $65 \mathrm{~cm}$, uma área intermediária menos elevada e uma área rebaixada adjacente. Por conta dessa peculiaridade morfológica, realizamos uma intervenção arqueológica, escavando três trincheiras de $3 \times 0,5 \mathrm{~m}$ em ambos os topos e na quota negativa

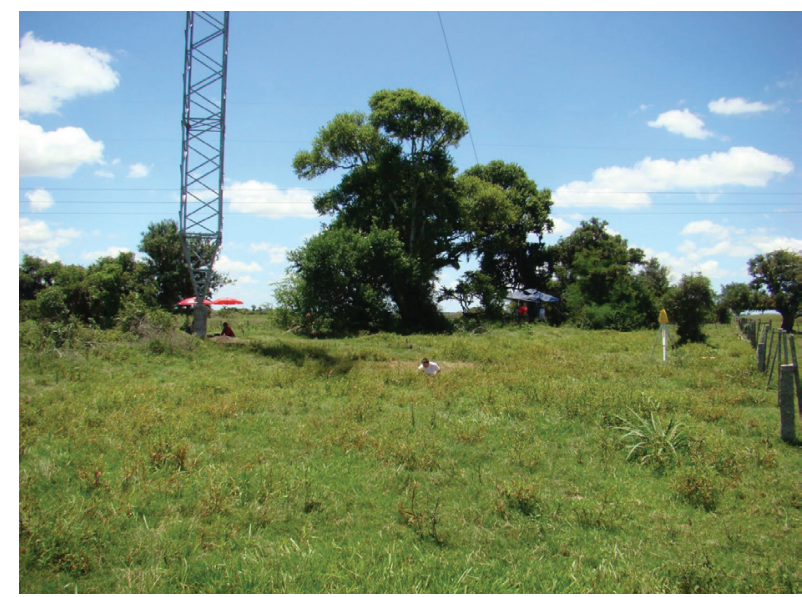

adjacente, assim como uma quadra de $1 \mathrm{~m}^{2}$ na área intermediária e poços teste ao longo da estrutura para delimitar horizontal e verticalmente as dimensões do cerrito. Foi coletada uma quantidade de 394 fragmentos cerâmicos, 103 materiais líticos e 17 ossos humanos.

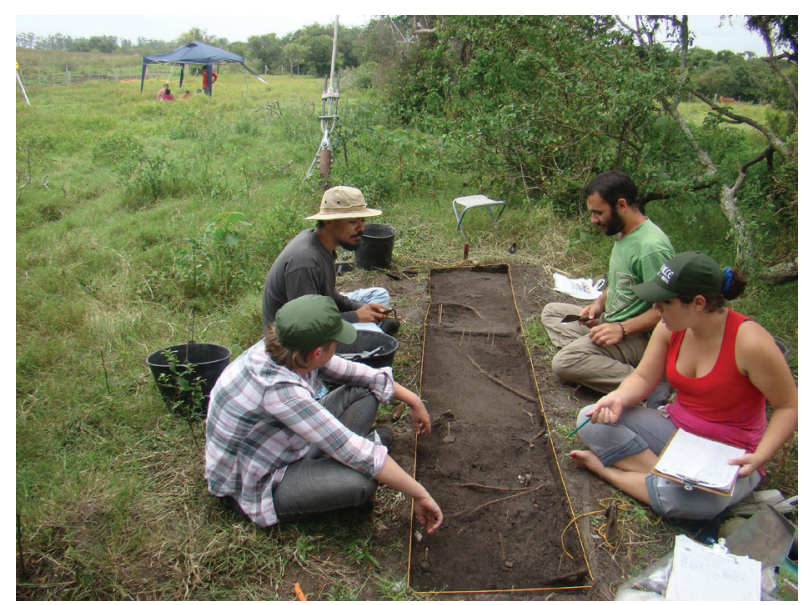

Figuras 16 e 17 - Vista geral do cerrito PSGLF-02 com escavação das três trincheiras e escavação da trincheira no topo do cerrito (nível 2). Note-se a torre de linha de transmissão construída no topo do sítio Fotos: Acervo LEPAARQ/UFPel. 

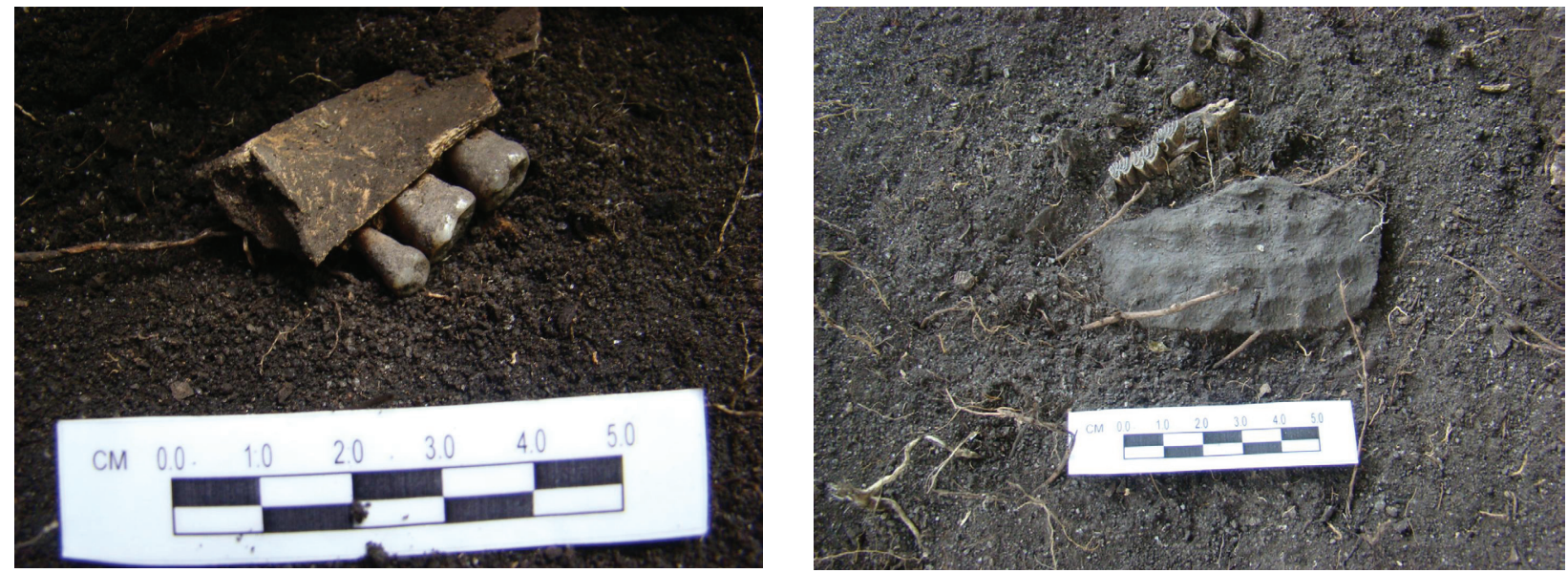

Figuras 18 e 19 - Escavação de mandíbula humana (nível 7) e fragmento de cerâmica com decoração digitada associada à mandíbula de cervídeo (nível 3)

Fotos: Acervo LEPAARQ/UFPel.

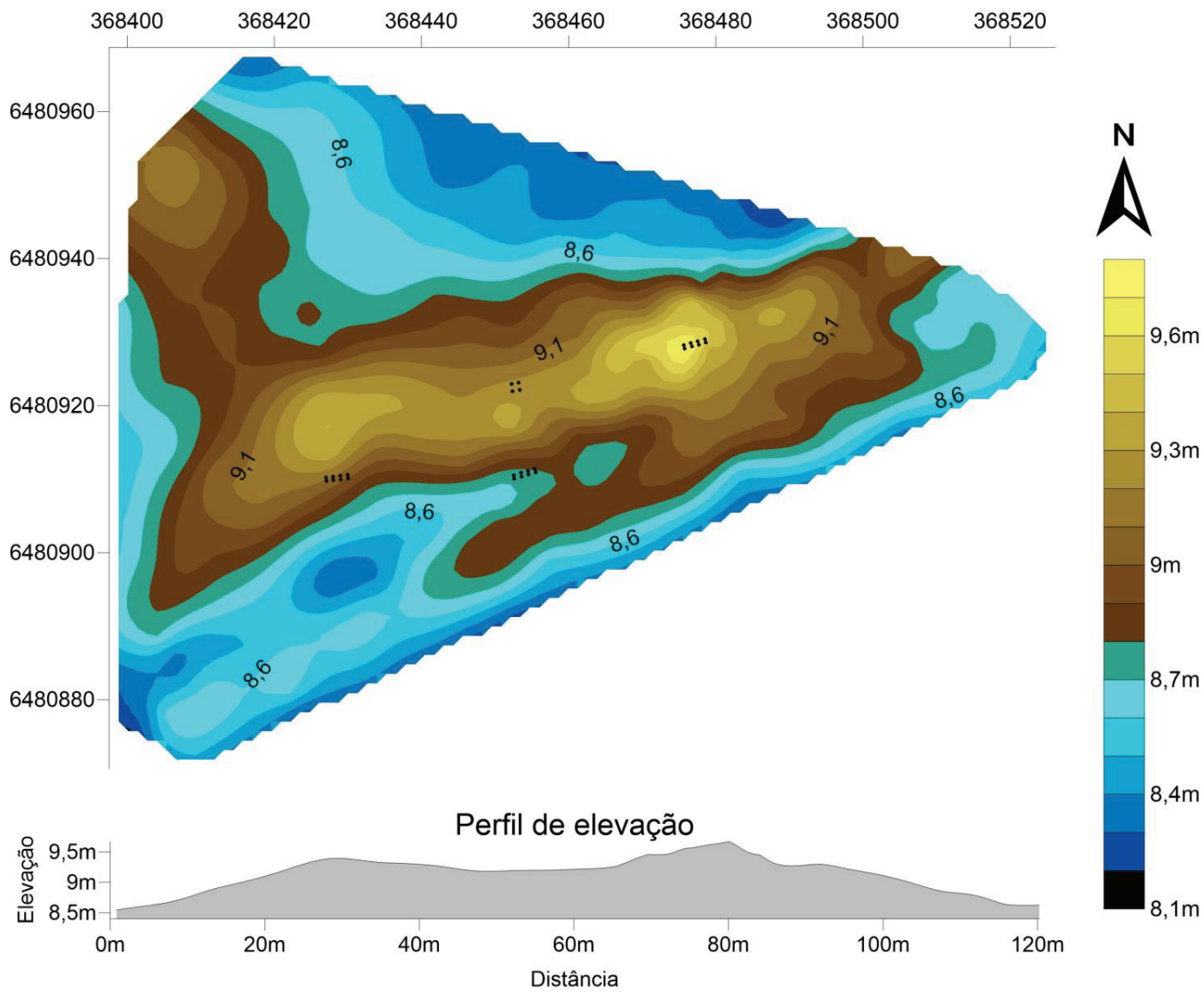

Figura 20 - Topografia do sítio PSGLF-02 apontando as sondagens efetuadas para delimitação da estrutura, as curvas de nível externas representam a área de banhado, portanto, o limiar do sítio

Fonte: Elaborada por Cleiton Silveira e Cristian Serpa.

\section{Tecnologia Cerâmica}

Para caracterização da coleção cerâmica do cerrito PSGLF-02, foram analisados 230 fragmentos cerâmicos maiores de $2 \mathrm{~cm}$ (de comprimento, largura ou espessura), divididos em 52 fragmentos de borda (22\%), 163 fragmentos de bojo (71\%) e 15 fragmentos de base (7\%). De modo geral, a coleção PSGLF-02 se trata de uma produção cerâmica majoritariamente roletada, em proporções semelhantes à verificada 
entre as coleções oriundas do Pontal da Barra ( $\mathrm{n}=218$; cerca de $95 \%$ dos fragmentos). Contudo, no que diz respeito ao tipo de queima, não existe predomínio claro entre os tipos verificados, uma vez que $54 \%$ da coleção apresenta indícios de queima incompleta $(n=124)$ contra $46 \%$ de queima completa $(n=106)$.

Apenas 11 vasilhas tiveram seu diâmetro inferido, variando entre $17 \mathrm{~cm}$ e $30 \mathrm{~cm}$ de abertura da boca do pote e as formas identificadas foram as mesmas anteriormente verificadas para as coleções do Pontal da Barra, em proporções semelhantes: contornos diretos, vasilhas abertas $(\mathrm{n}=6)$, fechadas $(n=2)$ ou paralelas $(n=1)$, com ocorrências de vasilhas muito abertas, tipo "prato" $(\mathrm{n}=2)$.
Com relação aos antiplásticos e aos tratamentos de superfícies verificados, similaridades com o Pontal da Barra também se fazem presentes, contudo em menor proporção e com menor variabilidade quanto aos tratamentos de superfície aplicados. Alisamentos dos tipos "fino" e "médio" foram os mais recorrentes, mas polimentos, banhos de argila e alisados com estrias regulares e irregulares também foram identificados. Entretanto, contrariamente às coleções do Pontal da Barra, nenhum dos fragmentos analisados apresentou indícios de tratamentos de superfície que envolvessem técnicas de "brunidura", como podemos ver no gráfico a seguir:

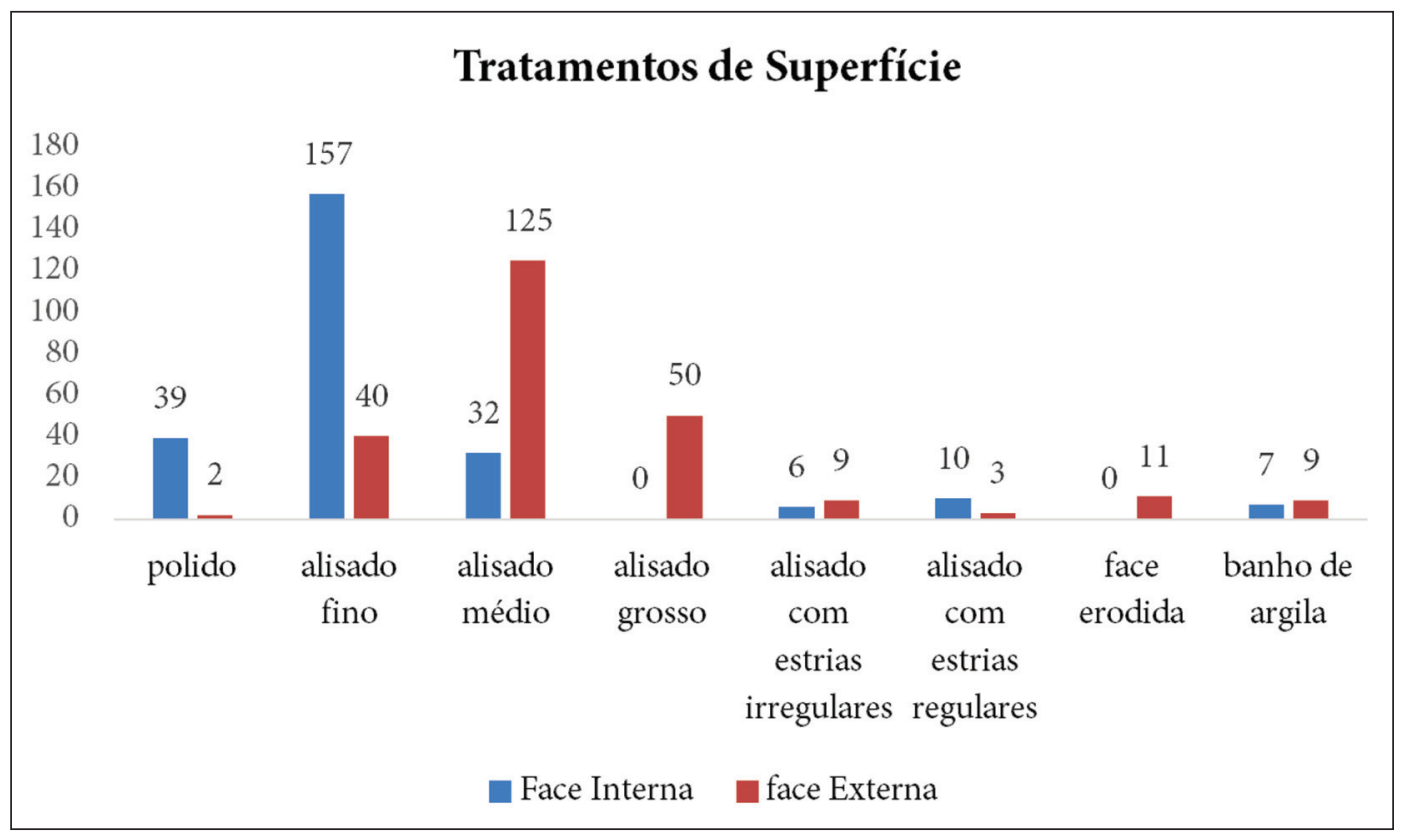

Gráfico 3 - Ocorrência de técnicas de tratamento de superfície Fonte: Elaborada por Bruno Leonardo Ricardo Ribeiro.

Quanto à presença de motivos decorativos, também similar às coleções do Pontal da Barra, decorações pintadas não foram identificadas e as decorações plásticas presentes na coleção PSGLF-02 não parecem diferir dos padrões presentes naquela coleção, neste caso restritos a faces externas digitadas $(\mathrm{n}=12)$ e lábios modelados $(\mathrm{n}=7)$.

Finalmente, os vestígios de utilização mais recorrentes na coleção foram, como esperado, os depósitos carbônicos em faces internas $(n=29)$ e as marcas de fuligem em faces externas $(n=54)$. $E$, além dá recorrente alta taxa de fragmentação, as atividades pós-deposicionais que mais impactaram a coleção parecem estar relacionadas a atividades pedológicas e tafonômicas, sendo as ocorrências mais frequentes a erosão de uma das faces ( $\mathrm{n}=59$ ocorrências em face interna e n=82 em face externa), concreções e crostas sedimentares $(n=97)$, negativos de radículas $(n=30)$ e presença de mofo $(n=26)$. 

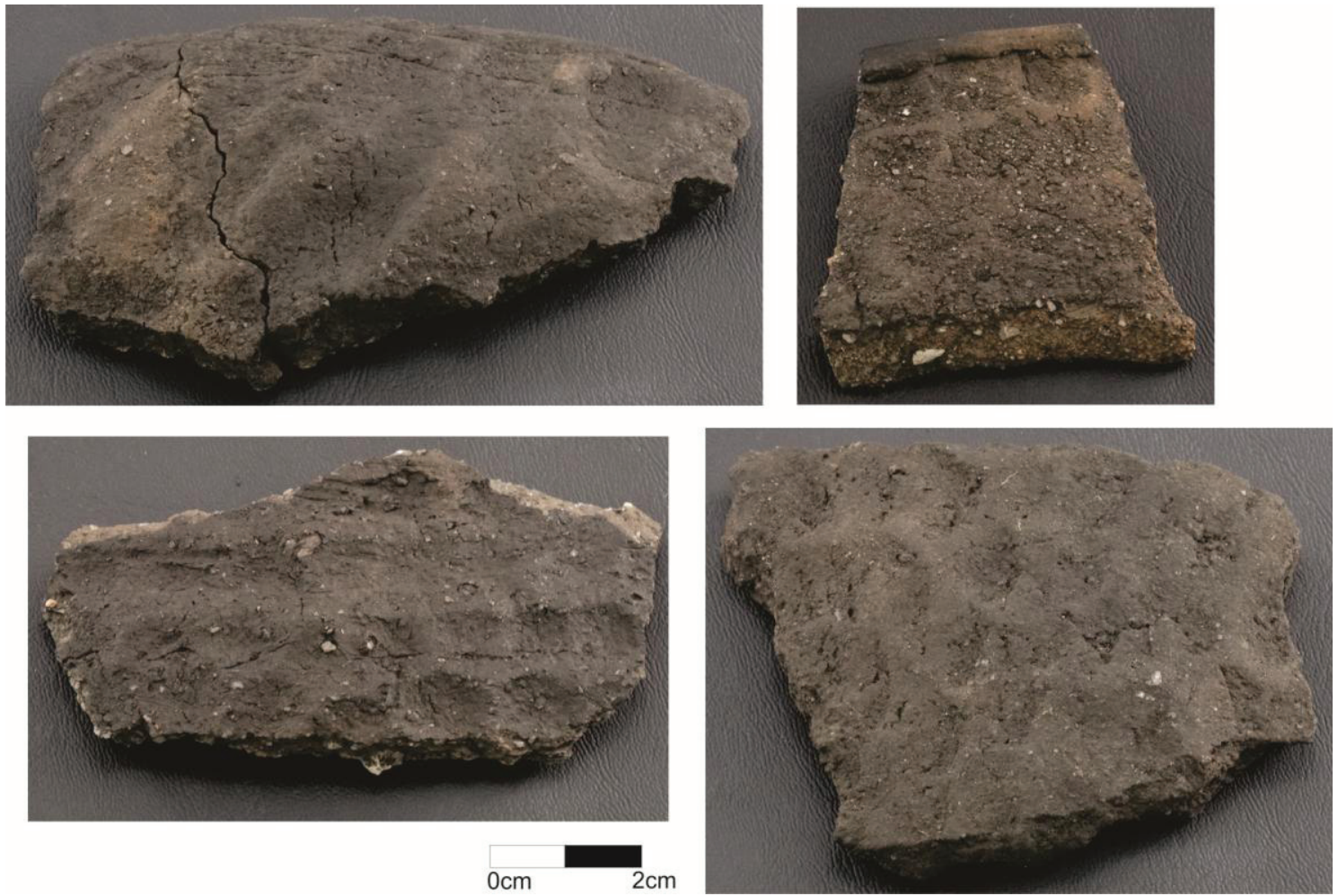

Figura 21 - Acima e à direita, lábio modelado com detalhe digitado; acima, à esquerda e abaixo, diferentes tipos de decoração digitada

Fonte: Elaborada por Bruno Leonardo Ricardo Ribeiro.

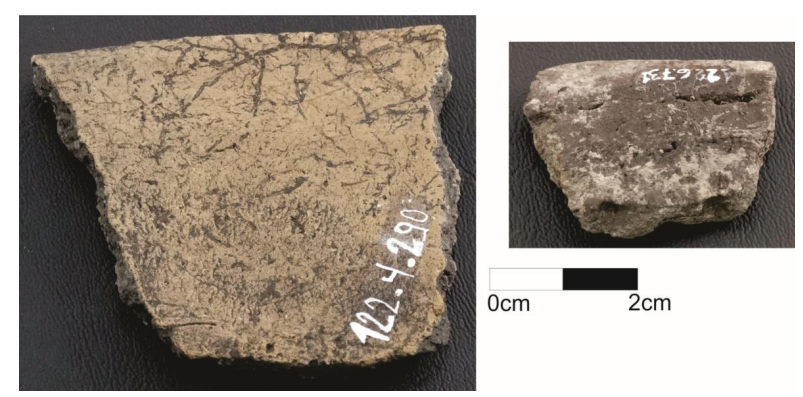

Figura 22 - À esquerda, fragmento de borda com negativos de radículas em face interna; à direita, fragmento de borda com intenso depósito de crosta sedimentar

Fonte: Elaborada por Bruno Leonardo Ricardo Ribeiro.

\section{Tecnologia Lítica}

Quanto à tecnologia lítica, os instrumentos provenientes do complexo de cerritos da Lagoa do Fragata, atingem uma soma de 134 objetos encontrados no sítio PSGLF-02. A porção conhecida dessa indústria lítica possui apenas artefatos de quartzo e granito, bem como outros objetos referentes às atividades de produção artefatual desempenhada no sítio, sendo 87 peças de quartzo e 47 peças de granito.
Foram identificados uma série de materiais a partir do empenho dessas rochas, em que as lascas bipolares, as estilhas e os resíduos angulosos se destacam numericamente frente aos demais: 49 resíduos, 28 lascas bipolares e 28 estilhas. Embora existam apenas cinco núcleos na coleção analisada, pode-se inferir, por meio dos materiais presentes na amostra, que a indústria lítica lascada foi baseada na redução bipolar de pequenos seixos de quartzo com bigorna.

Como exemplo das categorias materiais do PSGLF-02 destaca-se um objeto de quartzo com quatro curtas retiradas bifaciais que adequam a porção distal do artefato, criando uma unidade tecno-funcional transformativa apta para corte de superfícies consistentes (Figura 23). Na Figura 24 , pode-se visualizar que as retiradas se deram sequencialmente na face "a" e após na "b". A existência dessas retiradas bifaciais tornou esse instrumento diferente da maior parte de outros identificados entre os cerritos da região Sudoeste da Laguna dos Patos, caracterizados por conter geralmente instrumentos oriundos de técnica bipolar sem retoques. 

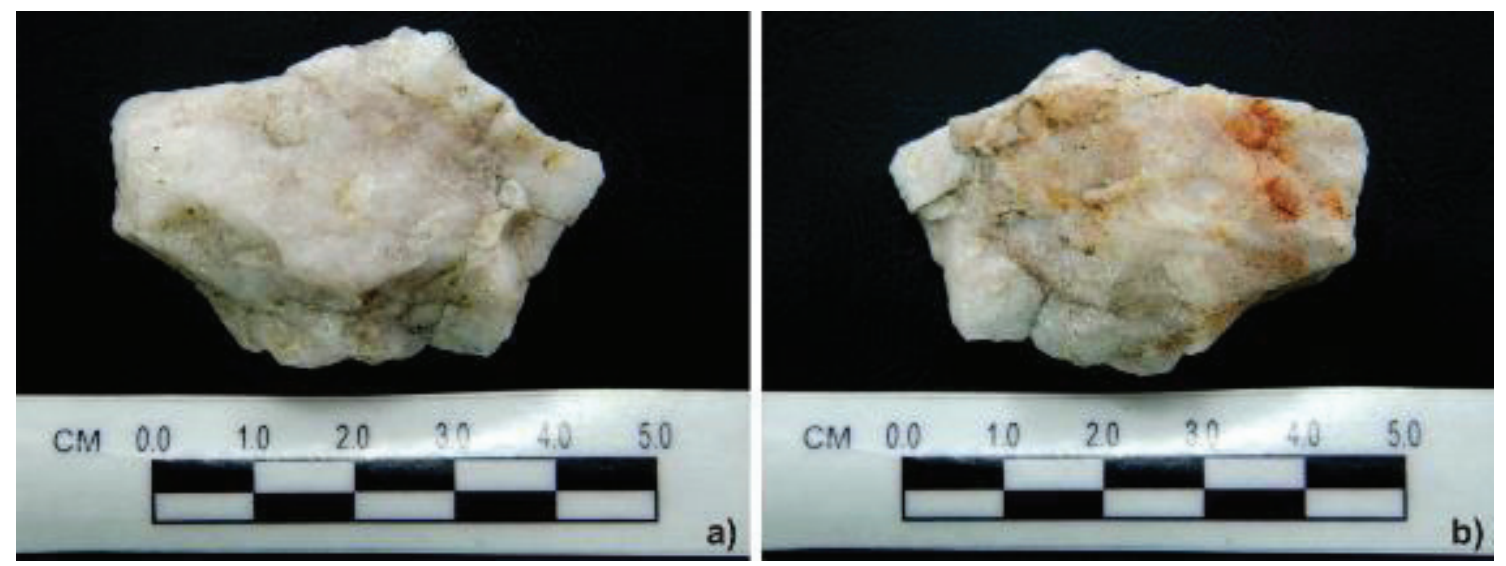

Figura 23 - Instrumento com unidade tecno-funcional transformativa apta para corte Fotos: Anderson Marques Garcia.

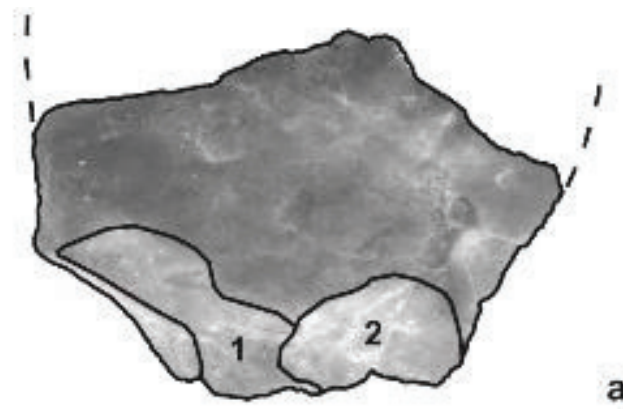

a)

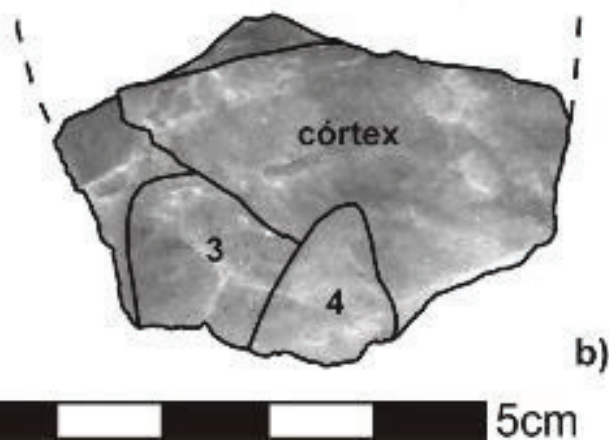

Figura 24 - a) ilustração diacrítica das retiradas bifaciais na área transformativa do artefato

Fotos: Anderson Marques Garcia.

\section{Vestígios arqueofaunísticos}

Quanto à arqueofauna, referente ao sítio PSGLF-02, cujos materiais arqueofaunísticos ainda se encontram em análise, esses correspondem até o momento, com que foi descrito para o cerrito PT-02 Cerrito da Sotéia por Ulguim (2010). Há um predomínio de vestígios ictiofaunísticos relacionados com Corvina (Micropogonias furnieri), Miraguaia (Pogonias cromis) e Bagre (Ariidade), reforçando a dieta identificada no cerrito da Ilha da Feitoria.

\section{Interpretação funcional do contexto arqueológico}

O levantamento topográfico e as intervenções arqueológicas realizadas no cerrito PSGLF2 apontam para uma discussão sobre a complexificação desse cerrito, no sentido de pensá-lo como uma construção "geminada" (IRIARTE, 2006; BRACCO; DEL PUERTO; INDA, 2008; VILLAGRAN; GIANOTTI, 2012). Podem ser observadas, na topografia, duas elevações distanciadas em aproximadamente $25 \mathrm{~m}$ interligadas por uma capa de sedimento, corroborando essa hipótese de terraplanagem para complexificação do espaço de moradia. Outro elemento a se destacar na topografia é a área adjacente ao cerrito que apresenta estruturas negativas com até $20 \mathrm{~cm}$ de profundidade, além das cotas naturais do terreno (ver modelagem topográfica a seguir). A hipótese de pesquisa levantada em nossas observações é de que essas estruturas sejam os pontos de retirada de sedimento para construção do montículo, caracterizando essa área adjacente como uma "zona de empréstimo" (GIANNOTTI, 2005, 2009; LOPEZ MAZZ; BRACCO, 2010; BRACCO; DEL PUERTO; INDA, 2008). 
Em contrapartida, os demais sítios estudados no complexo da Lagoa do Fragata (PSGLF-03, PSGLF-04, PSGLF-05, PSGLF-06 e PSGLF-07) não apresentam indícios de construção, sendo interpretados como albardões naturais ocupados. Considerando essa dicotomia entre sítios construídos e não construídos, pode-se propor a hipótese de que o complexo da Lagoa do Fragata é composto por áreas de moradia e acampamentos sazonais utilizados como área de abastecimento de áreas centrais de moradia semipermanente, como o sítio PSGLF-02, onde os indícios de ocupação intensiva são claros, ocorrendo, inclusive, sepultamentos secundários.

Devido ao tipo de intervenção exploratória realizado até o momento nos sítios em albardão, em que foi intensificada a delimitação dos depósitos arqueológicos com poços teste, não é possível estabelecermos projeções de NMI sobre a arqueofauna, nem determinarmos conversão de biomassa, para pensar em aspectos mais refinados de economia e dieta. No entanto, esses dados, ainda que exploratórios, já nos permitem ter um perfil do tipo de materiais mais abundantes nos sítios, possibilitando estabelecer comparações com as outras áreas de pesquisa na Laguna dos Patos e, até mesmo, alguns comparativos com os sítios do bioma Pampa.

\section{Discussão e conclusão}

O mapeamento arqueológico permitiu a identificação de complexos de sítios localizados em ambientes alagadiços, conhecidos regionalmente como banhados. Ocorrem cerritos construídos e sítios em albardões naturais, ambos os tipos de sítios ocupados pelos mesmos grupos indígenas. Os sítios construídos tendem a ter formatos elípticos e são nitidamente pontuais e circunscritos no terreno com altitudes que variam de 50 a $120 \mathrm{~cm}$, o que corresponde a sua potência estratigráfica. São compostos, desde o topo à base, por sedimento de cor cinza-escura/preta, cujos dados de química de sedimento realizados nos cerritos PSG-02 e PSG-06 do Pontal da Barra sugerem um enriquecimento antrópico, seja por ações intencionais e/ou pelo uso intensivo do espaço como áreas residenciais, sepultamentos dos mortos, depósito de lixo ou manejo de botânicos, ou seja, processos que envolvem quantidades significativas de matéria-orgânica. Entre os cerritos construídos que sofreram intervenções arqueológicas, onde também foram realizadas medições microtopográficas, ficou evidente a complexificação dos espaços arquitetônicos, ocorrendo nas suas áreas adjacentes "áreas de empréstimo" e "microrrelevos", como é o caso do conjunto dos cerritos PSG-02, PSG-05, PSG-06 e PSG-07, localizados no Pontal da Barra, e o cerrito PSGLF-02 do banhado da Lagoa do Fragata.

Os sítios não construídos, por sua vez, apresentam-se como albardões naturais ocupados. São encontrados materiais ao longo de extensas matas lineares que bordeiam os banhados da região, cuja potência estratigráfica dos sítios raramente ultrapassa $25 \mathrm{~cm}$ e apresentam um sedimento enegrecido por fatores de biodegradação da matéria-orgânica natural, havendo, é claro, contribuição menos intensiva se comparado aos cerritos construídos, de material depositado pelas ocupações humanas. Esse tipo de sítio foi mais bem evidenciado, até o momento, no complexo da Lagoa do Fragata. Nesse complexo, inclusive, é nítida a relação sistêmica desses sítios de ocupação fugaz, como o cerrito PSGLF-02, cuja interpretação funcional caminha no sentido de ser uma área de moradia, utilizada também como lugar de sepultamento dos mortos. Somando-se os fatores altura e formato, é possível inferir que os sítios realmente não sejam construções, mas áreas de ocupação de pontos no terreno naturalmente mais elevados, que se configuram como áreas alongadas seguindo o padrão da linha de deposição sedimentar natural.

Outro fator de caracterização interessante desses sítios é a sua baixa volumetria. Os sítios da região de Pelotas não ultrapassam os 1,20 m de altura, enquadrando-se no perfil dos sítios da Laguna dos Patos, que também não passam de $2 \mathrm{~m}$, como apontado por Schmitz (1976). Essa baixa volumetria, no entanto, contrasta com alguns contextos de sítios do Uruguai, onde há cerritos com até $7 \mathrm{~m}$ de altura, cuja proeminência é visível a longas distâncias na paisagem. Se por um lado, há baixa volumetria dos sítios, por outro lado, é interessante apontar a alta frequência de materiais cerâmicos nesses sítios, associados a um massivo registro de fauna 
ictioarqueológica. Fatores esses que, associados (baixa volumetria, grande frequência cerâmica e abundância de fauna lacustre) parecem sugerir um registro particular da região da Laguna dos Patos, que contrasta, mais uma vez, com contextos de outras regiões onde ocorre o fenômeno dos montículos de terra.

Ao isolarmos as técnicas de produção verificadas dentre as coleções cerâmicas da Lagoa do Fragata e do Pontal da Barra, certas similaridades tecnológicas eclodem, o que pode ser indicativo de certo modo de fazer cerriteiro, que sugere que as mesmas populações ocuparam os sítios construídos e os não construídos: constrições técnicas de caráter cultural dentro das quais os artesãos e as artesãs do grupo estariam operando e produzindo vasilhames cerâmicos que seriam, de fato, vasilhames "cerriteiros". Verificamos, dentre as coleções analisadas de maneira mais aprofundada (PSG-03; PSG-04, PSG-07 e PSGLF-02), grandes similaridades tecnológicas em praticamente todas as etapas de confecção dos vasilhames - produção majoritariamente roletada, com técnicas de acabamentos de superfície semelhantes e aplicação dos mesmos motivos decorativos predominantemente nas zonas da borda e lábio dos vasilhames - o que nos possibilitou, inclusive, tomar um destes aspectos como "elemento diagnóstico" dessa parentela tecnológica: os lábios modelados.

Essa diversidade de tipos de sítios arqueológicos construídos - onde ocorrem transformações topográficas negativas e positivas adjacentes e sítios não construídos - sugere uma ampla gama de formas arquitetônicas e funções sistêmicas de uma mesma população "cerriteira" que se, por um lado, desafiam a compreensão arqueológica desses fenômenos, por outro lado, apontam o grande potencial da arqueologia dos cerritos da Laguna dos Patos, tema adormecido ou timidamente estudado nos últimos 40 anos. Além disso, a grande variedade de tipos de sítios associados aos grupos construtores de cerritos chama atenção para a ampla diversidade patrimonial que merece ser observada atentamente pelas políticas de gestão do patrimônio, a fim de impedir a perda desses espaços de memória e história de longa duração em virtude do atendimento de demandas imobiliárias ou empresariais, que colocam em risco a integridade dos elementos materiais da História indígena regional.

\section{Notas}

1 Sugerimos ver, também, Basile-Becker (1992, 2002), Lopez Mazz (2001), Garcia e Milder (2012).

2 As formas das vasilhas são semelhantes às encontradas nos cerritos do Pontal da Barra e podem ser visualizadas na prancha de formas da Figura 7.

3 Essa data recuada de 2.000 anos A.P. se dá em função do modelamento estatístico, porém é possível que as datações recuem até aproximadamente 2.500 anos A.P., conforme $\mathrm{o}$ a data convencional aponta.

\section{Referências}

BASILE-BECKER, Í. I. O que sobrou dos índios pré-históricos do Rio Grande do Sul, In: KERN, A. A. (Org.). Arqueologia Pré-Histórica do Rio Grande do Sul. Porto Alegre: Mercado Aberto, 1992. p. 331-356.

Os Índios Charruas e Minuanos na Antiga Banda Oriental do Uruguai. São Leopoldo: Editora Unisinos, 2002.

\section{BELLETTI, J. Uns caquinhos num montão de terra:} o que fazer com eles? Discussões sobre cerritos no sudoeste da Laguna dos Patos (Rio Grande do SulBrasil). 2010. 202 f. Trabalho de conclusão de curso (Graduação em História) - Universidade Federal de Pelotas, Pelotas, 2010.

BOADO, F. C.; GIANOTTI, C.; BORRAZÁS, P. M. Before the barrows: forms of monumentality and forms complexity. In: SMEJDA, L. (Ed.). Iberia and Uruguay. Archaeology of Burial Mounds. Plzen: University of West Bohemia, 2006. p. 38-52.

BONOMO, M. Historia Prehispánica de Entre Ríos. Buenos Aires: Fundación de Historia Natural Félix de Azara; Universidad Maimónides, 2012.

.; POLITIS, G.; GIANOTTI, C. G. Montículos, jerarquía social y horticultura en las sociedades indígenas del delta del Río Paraná (Argentina). Latin American Antiquity, v. 22, n. 3, p. 297-333, 2011. 
BRACCO, R.; CABRERA, L.; LOPEZ MAZZ, J. M. La prehistoria de las Tierras Bajas de la Cuenca de la Laguna Merín. In: COIROLO, A. D.; BRACCO, R. (Ed.). Arqueología de las Tierras Bajas. Montevideo: Ministerio de Educación y Cultura, 2000. p. 13-38.

.; DEL PUERTO, L.; INDA, H. Prehistoria y Arqueología de la Cuenca de Laguna Merín. In: LOPONTE, D.; ACOSTA, A. (Comp.). Entre la Tierra y el Agua. Arqueología de Humedales de Sudamérica. Buenos Aires: AINA, 2008. p. 1-60.

BRASIL. Secretaria do Planejamento da Presidência da República. Radambrasil. Levantamento de Recursos Naturais, Volume 33 - Folha SH.22 Porto Alegre e parte das folhas SH 21 Uruguaiana e SI.22 Lagoa Mirim. Rio de Janeiro: IBGE, 1986. v. 33. Disponível em: <http://biblioteca.ibge.gov.br/ visualizacao/livros/liv19048_a.pdf $>$. Acesso em: 10 abr. 2016.

BRONK RAMSEY, C.; LEE, S. Recent and planned developments of the program OxCal. Radiocarbon, v. 55, p. 720-730, 2013.

CABRERA, L. Construcciones en tierra y estructura social en el Sur del Brasil y Este de Uruguay (Ca. 4.000 a 300 a. A.P.) Revista Techné, Portugal, n. 1, p. 25-33, 2013.

CAPDEPONT, I.; DEL PUERTO, L.; INDA, H. Caracterización tecnológica y funcional del material cerámico arqueológico de la cuenca de la Laguna de Castillos (Rocha - Uruguay). In: MAZZANTIN, D.; BÉRON, M.; OLIVA, F (Ed.). Del Mar a los salitrales. Diez mil años de historia Pampena en el umbral del tercer milenio. Mar del Plata: Facultad de Humanidades, UNMdP, SAA, 2002. p. 41-50.

COPÉ, S. M. A ocupação pré-colonial do Sul e Sudeste do Rio Grande do Sul. In: KERN, Arno Alvarez (Org.). A Arqueologia Pré-histórica do Rio Grande do Sul. Porto Alegre: Mercado Aberto, 1992, p. 191-220

COPÉ, S. M. II relatório parcial da prospecção intensiva na LT $230 \mathrm{KV}$ nova Santa Rita - Camaquã 3 - Quinta, RS. Porto Alegre, 2014.
GARCIA, A. M. As Cadeias Operatórias de uma indústria tecnológica lítica: sítio arqueológico PT-02 (Cerrito da Sotéia), Pelotas/RS. 2010. 126 f. Trabalho de Conclusão de Curso (Graduação em Geografia) - Universidade Federal de Pelotas, Pelotas, 2010.

Sítio arqueológico do Pororó: um cerrito na mesoregião centro ocidental riograndense (Pinhal Grande). 2012. 113 f. Dissertação (Mestrado Profissionalizante em Patrimônio Cultural) Programa de Pós-Graduação em Patrimônio Cultural, Universidade Federal de Santa Maria, Santa Maria, 2012.

.; MILDER, S. E. S. O lugar do ameríndio na sociedade sul rio-grandense: ancestralidade mitos originários e o imaginário popular. In: PAIM, E. A.; GUIMARÃES, M. de F. (Org.). História, Memória e Patrimônio: Possibilidades Educativas. 1. ed. Jundiaí: Paco Editorial, 2012. p. 131-147.

.; MILHEIRA, R. G. As cadeias operatórias líticas do Sítio PT-02 (Cerrito da Sotéia), Ilha da Feitoria, Pelotas-RS: uma hipótese interpretativa referente ao aproveitamento litológico no litoral sudoeste da Laguna dos Patos. Cadernos do LEPAARQ, n. VIII, n. 15/16, p. 41-82, 2011.

.; _. Gestão de fontes de matéria-prima lítica pelos construtores de cerritos no sul do Brasil: um estudo de caso. Espaço Ameríndio: UFRGS, v. 7, p. 10-36, 2013.

. Monumentalidad, ceremonialismo y continuidad ritual. In: (Coord.). Paisajes Culturales Sudamericanos, TAPA 19. Laboratorio de Arqueoloxía e Formas Culturais (USC), Santiago de Compostela, 2000. p. 87-102.

GIANOTTI, C.; DEL PUERTO, L.; INDA, H.; CAPDEPONT, I. Construir para producir. Pequeñas elevaciones en tierra para el cultivo de maíz en el sitio Cañada de los Caponcitos, Tacuarembó (Uruguay). Cuadernos del Instituto Nacional de Antropología y Pensamiento Latinoamericano - Series Especiales, v. 1 n. 1, p. 12-25, 2013. 
GONZALEZ, M.; MILHEIRA, R. G. Reinterpretando o Zoomorfo de Tubarão da Coleção "Carla Rosane Duarte Costa”. Cadernos do LEPAARQ, v. 2, n. 4, 2004, p. 87-98.

HOGG, A.; HUA, Q.; BLACKWELL, P.; NIU, M.; BUCK, C.; GUILDERSON, T.; HEATON, T.; PALMER, J.; REIMER, P.; REIMER, R.; TURNEY, C.; ZIMMERMAN, S. SHCal13 Southern Hemisphere Calibration, 0-50,000 Years cal BP. Radiocarbon, n. 4, 55, p. 1889-1903, 2013.

IRIARTE, J. Transformation, Mounded Villages and Adopted Cultigens: The Rise of Early Formative Communities in South-Eastern Uruguay. World Archaeology, v. 38, n. 4, p. 644-663, 2006.

LOPEZ MAZZ, J. M. Las estructuras tumulares (cerritos) del Litoral Atlántico uruguayo. Latin American Antiquity, v. 12, p. 1-25, 2001.

.; GIANOTTI, C. Construción de espacios cerimoniales públicos entre los pobladores prehistoricos de las tierras bajas de Uruguay: el estudio de organización espacial en la localidad arqueológica Rincón de los Indios. Revista da Sociedade de Arqueologia Brasileira, v. 11, p. 87106, 1998.

; BRACCO, D. Minuanos. Apuntes y notas para la historia y la arqueología del territorio GuenoaMinuan (Indígenas de Uruguay, Argentina y Brasil). Montevideo: Linardi y Risso, 2010.

LOPONTE, D. Arqueología del Humedal del Paraná Inferior (Bajíos Ribereños Meridionales). Buenos Aires: Asociación Amigos del Instituto Nacional de Antropología y Pensamiento Latinoamericano, 2010. ; ACOSTA, A. El registro del tramo final de la cuenca del Plata. In: (Comp.). Entre

la Tierra y el Agua. Arqueología de Humedales de Sudamérica. Buenos Aires: Asociación Amigos del Instituto Nacional de Antropología y Pensamiento Latinoamericano, 2008. p. 125-164.

LOUREIRO, A. G. Sítio PT-02-Sotéia: Análise dos Processos Formativos de um Cerrito na Região
Sudoeste da Laguna dos Patos/RS. 2008. 89 f. Dissertação (Mestrado em Arqueologia) - Programa de Pós-Graduação em Arqueologia, Universidade de São Paulo, São Paulo, 2008.

MAUHS, J.; MARCHIORETTO, M. S. Formações vegetais do litoral central. Pesquisas, Antropologia, n. 63, p. 115-122, 2006.

MAURICIO, G. N.; DIAS, M. New distributional information for birds in southern Rio Grande do Sul, Brazil, and the first record of the Rufous Gnateater Conopophaga lineate for Uruguay. Bull. Brit. Ornith. Club, v. 120, n. 4, p. 230-237, 2000.

MENTZ RIBEIRO, P. A. M., PENHA, M. A. P., FREITAS, S. E.; PESTANA, M. B. A Ocorrência de Zoólitos no Litoral Centro e Sul do Rio Grande do Sul, Brasil. Rio Grande: FURG, 2002.

MILHEIRA, R. G. Esculturas Líticas Sambaquieiras: Algumas Possibilidades Interpretativas. Reflexões a partir de uma Coleção Lítica do LEPAARQ UFPEL. 2005. 84 f. Trabalho de Conclusão de Curso (Graduação em História) - Universidade Federal de Pelotas, Pelotas, 2005.

Entre o desenvolvimentismo e a preservação do patrimônio. O caso do Pontal da Barra, no sul do Brasil, Pelotas-RS. In: MUNOZ, J. G. Ser de Imagen y de Signo: abordajes sobre el Patrimonio Cultural. Venezuela: Fondo Editorial de la Universidad Latinoamericana y del Caribe (FEULAC), 2015. p. 16-38.

.; PEÇANHA, M. G.; MÜHLEN, C. V. Mapeamento Arqueológico dos Cerritos da Lagoa do Fragata, Capão do Leão-RS. In: CAMPOS, J. B.; ZOCCHE, J. J.; CEREZER, J. F.; OOSTERBEEK, L. M. (Org.). Arqueologia Ibero-americana e Transatlântica: Arqueologia, Sociedade e Território. Erechim: Habilis, 2014. p. 51-70.

MILHEIRA, R. G.; MACARIO, K. D.; CHANCA, I. S.; ALVES, E. Q. Archaeological earthen mound complex in Patos Lagoon, Southern Brazil: chronological model and freshwater influence. Radiocarbon, 2017. No prelo. 
MÜHLEN, C. V. Humanos, plantas e paisagem: a Arqueopalinologia como ferramenta para análise dos processos formativos do Cerrito PSG-02 Valverde, Pelotas, RS. 2014. 79 f. Trabalho de Conclusão de Curso (Graduação em Antropologia) - Universidade Federal de Pelotas, Pelotas, 2014.

NEBEL, G. C. da S. Conflitos ambientais no Pontal da Barra - Pelotas/RS - desde uma perspectiva etnográfica na educação ambiental. 2004. 206 f. Dissertação (Mestrado em Educação Ambiental) - Programa de Pós-Graduação em Educação Ambiental, Universidade Federal de Rio Grande, Rio Grande, 2014.

PEÇANHA, M. G. Mapeamento arqueológico dos cerritos da Lagoa do Fragata, Pelotas e Capão do Leão-RS. 2014. 162 f. Dissertação (Mestrado em Antropologia) - Programa de Pós-Graduação em Antropologia, Universidade Federal de Pelotas, Pelotas, 2014.

PINTOS BLANCO, S. Cazadores recolectores Complejos: Monumentalidad en tierra en la Cuenca de la Laguna de Castillos (Uruguay). In: GIANOTTI, C. (Coord.). Paisajes Culturales Sudamericanos, TAPA 19. Santiago de Compostela: Laboratorio de Arqueoloxía e Formas Culturais (USC), 2000. p. $75-86$.

QUINTANA, V. B. Lugares Pensados, Lugares Transformados, Lugares Vividos: os cerritos do Banhado do M'Bororé enquanto manifestações de uma cultura local. 2010. 126 f. Dissertação (Mestrado em História) - Programa de Pós-Graduação em História, Pontifícia Universidade Católica do Rio Grande do Sul, Porto Alegre, 2010.

REIMER, P.; BARD, E.; BAYLISS, A.; BECK, W.; BLACKWELL, P.; BRONK RAMSEY, C.; GROOTES, P.; GUILDERSON, T.; HAFLIDASON, H.; HAJDAS, I.; HATTÉ, C.; HEATON, T.; HOFFMANN, D.; HOGG, A.; HUGHEN, K.; KAISER, F.; KROMER, B.; MANNING, S.; NIU, M.; REIMER, R.; RICHARDS, D.; SCOTT, M.; SOUTHON, J.; STAFF, R.; TURNEY, C.; VAN DER PLICHT, J. IntCal13 and Marine13 Radiocarbon Age Calibration Curves 0-50,000 Years cal BP. Radiocarbon, v. 55, p. 1869-1887, 2013.
RIBEIRO, B. L. R.; MILHEIRA, R. G. A Cerâmica dos Cerritos no Pontal da Barra - Pelotas/RS: Por Uma (Necessária) Revisão Conceitual da Tradição Vieira. Teoria e Sociedade, n. 23, p. 95-124, 2015.

RIZZINI, C. T. Tratado de fitogeografia do Brasil. Rio de Janeiro: Âmbito Cultural, 1997.

RÜTHSCHILLING, A. Pesquisas Arqueológicas no Baixo Rio Camaquã. Documentos, 3, p. 7-106, 1989.

SCHMIDT, M.; HECKENBERGER, M. Amerindian Anthrosols: Amazonian Dark Earth Formation in the Upper Xingu. In: WOODS, W.; TEIXEIRA, W.; LEHMANN, J.; STEINER, C.; WINKLERPRINS, A.; REBELLATO, L. (Ed.). Amazonian Dark Earths: Wim Sombroek's Vision. USA: Springer Science, 2009. p. 163-192.

SCHMITZ, P. I. Sítios de Pesca lacustre em Rio Grande, RS, Brasil. 1976. 280 f. Tese (Livre Docência) - Pontifícia Universidade do Rio Grande do Sul, Porto Alegre, 1976.

SELMO, F.; ASMUS, M. Análise ambiental da ocupação urbana do Pontal da Barra, praia do Laranjal, Pelotas, RS. Cadernos de Ecologia Aquática, v. 1, n. 2, p. 30-37, 2006.

SERRANO, A. The Charrua. In: STEWARD, J. (Org.). Handbook of South American Indians: The Marginal Tribes. Washington, DC: Smithsonian Institution, 1946. p. 191-196.

SILVA, F. A. A Tecnologia e seus Significados. Um Estudo da Cerâmica dos Asuriní do Xingu e da Cestaria dos Kayapó-Xikrin sob uma Perspectiva Etnoarqueológica. 2000. 265 f. Tese (Doutorado em Arqueologia) - Programa de Pós-Graduação em Arqueologia, Universidade de São Paulo, São Paulo, 2000.

SOARES, G. F. de. Análise de palinomorfos de 3 níveis estratigráficos do cerrito PSG - 01, Pelotas, RS/Brasil. 2014. 82 f. Monografia (Graduação em Arqueologia) - Universidade Federal de Rio Grande, Rio Grande, 2014. 
TEIXEIRA, W.; MARTINS, G. C.; MACEDO, R. S.; NEVES JÚNIOR, A.; MOREIRA, A.; BENITES, V. de. M.; STEINER, C. As propriedades físicas e hídricas dos horizontes antrópicos (Terras Pretas de Índio e Terras Mulatas) na Amazônia. In: TEIXEIRA, W.; KERN, D. C.; MADARI, B. E.; LIMA, H. N.; WOODS, W. (Org.). As Terras Pretas de Índio da Amazônia: sua caracterização e uso deste conhecimento na criação de nova áreas. 1. ed. Manaus: Editora da Universidade Federal do Amazonas; Embrapa Amazônia Ocidental, 2010. p. 242-250.

TOMAZELLI, L. J.; VILLWOCK, J. A. O Cenozóico no Rio Grande do Sul: Geologia da Planície Costeira. In: HOLZ, M.; DE ROS, L. F. (Ed.). Geologia do Rio Grande do Sul. Porto Alegre: CIGO/UFRGS, 2000. p. 375-406.

ULGUIM, P. Zooarqueologia e o Estudo dos Grupos Construtores de Cerritos: Um Estudo de Caso no Litoral da Laguna dos Patos - RS, Sítio PT-02 Cerrito Da Sotéia. 2010. 245 f. Trabalho de Conclusão de Curso (Graduação em História) - Universidade Federal de Pelotas, Pelotas, 2010.
VENZKE, T. S.; FERRER, R. S.; COSTA, M. A. D. da. Florística e análise de similaridade de espécies arbóreas da mata da praia do Totó, Pelotas, RS, Brasil. Ciência florestal, v. 22, n. 4, p. 655-668, 2012.

VIANA, J. O.; PEIXOTO, L. Diagnóstico interventivo e prospecção arqueológica intensiva para a obra da adutora do sistema de abastecimento de água ETA - São Gonçalo, Pelotas e Capão do Leão/RS. Pelotas, 2015.

VILLAGRAN, X.; GIANOTTI, C. Earthen mound formation in the Uruguayan lowlands (South America): micromorphological analyses of the Pago Lindo archaeological complex. Journal of Archaeological Science, v. 40, p. 1093-1107, 2013.

VILLWOCK, J. A.; TOMAZELLI, L. J.; LOSS, E. L.; DEHNHARDT, E. A., HORN FILHO, N. O.; BACHI, F. A.; DEHNHARDT, B. A. Geology of the Rio Grande do Sul coastal province. Quaternary of South America and Antarctic Peninsula, n. 4, p. 79-97, 1986. 